\title{
Lakis kratere og lavastromme
}

af

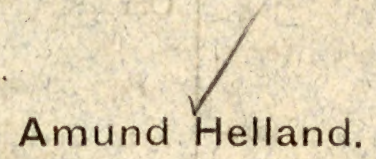

400

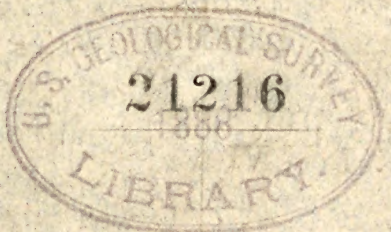

Universitetsprogram for 2let semester 1885 .

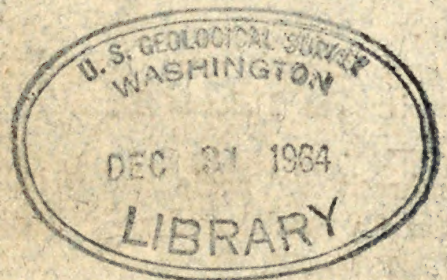

Kristiania.

Trykt i Gentraltrykkeriet. 1886. 


\section{Lakis kratere og lavastremme}

af
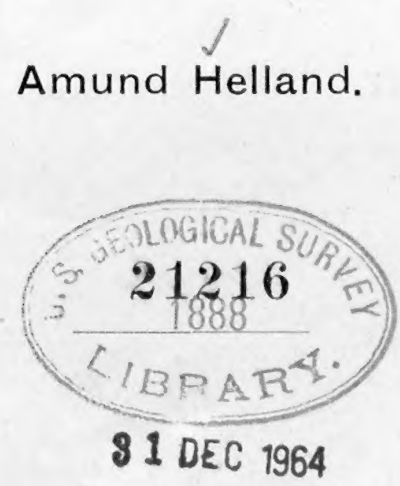

Universitetsprogram for 2det semester 1885.

Kristiania.

Trykt i Cenfraltrykkeriet.

1886. 
Sydligt paa Island ligger en bygd, Siða, som paa en mærkværdig maade er skilt fra udenverdenen ved lavastromme, jøkler, orkner og stride elve samt ved en havnles, sandet kyst, hvor intet skib kan lande.

Helt vestligt ifra Eyrarbakki i Árnessýsla og til Papós i Austr Skaptafellssýsla har Islands sydkyst ingen havn, og landet gaar ud til havet mest som en ode sand paa hele 350 kilometers længde.

I ikke stor afstand fra den sandede kyst stiger landet, mest raskt til høie jokler, og der bliver da tilbage mellem havet $\mathrm{og}$ det hoie land en smal, flad rand, der vel oftest er ode og stenet, men som dog paa mange steder giver dyrkbart land.

Paa en strækning, ikke mindre end 150 kilometer lang, danner den 8510 kvadratkilometer store Vatnajøkull det høie land langs kysten, og længer vestligt ligger paa en strækning af 50 kilometer Mýrdalsjekull (1021 km.2) med Ey'jafjallajekull over den flade strand. Disse store jokler virker som umaadelige kondensatorer for vanddampene i luften, der fores ind over fra havet, og regnmængden er derfor høi, i Berufjordr, den meteorologiske station nærmest Vatnajokull, $1007 \mathrm{~mm}$. Sandsynligvis er regnmængden endnu meget storre oppe paa jøkelen, der i den del, som kaldes Oræfajøkull, naar Islands største høide, 1959 meter.

Da joklerne er store, og regnmængden høi, saa er de elve, som kommer frem, hverken smaa eller faa $\mathrm{i}$ antal, og da de flyder over fladt, stenet $\mathrm{g}$ sandet land, saa vexler de ideligt løb, og tilintetgjor derved ethvert haab om brobygning og veibygning paa store dele af kysten. At bygge en varig vei for den sydlige del af Island bliver end mere umuligt derved, at der under joklernes is ligger vulkaner, som nu og da har udbrud.

Under deslige udbrud flommer vand $\mathrm{og}$ is $\mathrm{og}$ dynd ud over kvadratmile store strækninger af 'det foranliggende flade land, $o g$ man har i Islands annaler ei alene exempler paa, at kirker og gaarde er blevne feiet bort under deslige sjokullhlaup , men hele præstegjæld er blevne omdannet, $o g$ havet udenfor er blevet udfyldt til tort land, saa at man rider der, hvor folk i gammel tid fiskede paa dybt vand, og der hror Islands landnamsmænd kunde seile ind, som i Kerlingarfjerdr, der er nu sandfyldt dal.

De grumsede jøkelelve, som med stadigt skiftende leie strommer over de ode sande, gjør reisen langs sydkysten besværlig, og flere af elvene, som den af svolvvandstof stinkende Fitlilakr og den berygtede Fokulsá á Breidamerkursandi, er det helt uhyggeligt at ride over.

Veien til Sida og den egn, med hvilken ri her kommer til at beskjæeftige os, er temmelig besværlig, hvad enten man kommer vest fra Reykjavík, eller man kommer fra de ostlige fjorde. 
Den vil under nogenlunde gunstige omstændigheder tage en uges tid paa hesteryggen fra morgen til aften, hvis man ikke har ualmindelig gode heste. Men det er i naturhistorisk henseende en af de mærkværdigste excursioner, man kan gjøre; thi de vidtstrakte, høie, skjoldformede bræer, de endelose sande med sine elve, lavastrommene, kraterne, de besynderlige fjeldformer baade ud i mod havet $\mathrm{og} \mathrm{i}$ de af bækkene udgravede gjel, ligesom de talrige gangdannelser og vexlende ældre og yngre bergarter gjør denne kyststrækning til et geologisk unicum, og de eiendommelige storartede udsigter, der aabner sig langs Islands sydkyst, vil stadigen være en behagelig overraskelse for den, der beholder en god helbred paa reisen.

- De orografiske forhold omkring Siða er saa eiendommelige, at det ikke er godt at give en oversigt uden ved hjælp af kart; her er da vedføiet et kart i maalestokken 1/150000. Til udarbeidelsen af kartet har jeg brugt ældre karter fra forrige aarhundrede if Magnus Stephensen og Sveinn Pálsson og derhos selvfolgelig Bjorn Gunnlaugssons bekjendte kart med de af Th. Thoroddsen i denne egn foretagne rettelser. Krrtet over selve den kraterrække, som i det følgende skal beskrives, er tegnet udelukkende efter de af mig paa stedet tagne skizzer og maalinger, ligesom hele den nordlige del af kartet er tegnet efter egne og Sveinn Pálssons iagttagelser. Min ledsager paa Islandsfærden, amanuensis ved Universitetsbibliotheket Andr. M. Hansen har hjulpet til med arbeidet baade paa Island og senere.

Kartet vil tjene til at give en oversigt over det hele; at det ofte er unøiagtigt i detaillen, ja maaske endog i enkelte væsentlige træk, saa at en senere opmaaling vil kunne paavise mange feil, er selvsagt $o g$ vil fremgaa deraf, at kartet omfatter over 50 kvadratmil, og at vi kun har arbeidet en uges tid i denne egn, men da ogsaa temmelig anstrengt, skjønt med daarlig udrustning og med faa instrumenter, nu $\mathrm{og}$ da forulempet af taage, som kom drivende. Det lange kart over selve kraterrækken eller ildlinien er derimod temmelig noiagtigt; thi denne har vi fulgt fod for fod, og her er, som man ser, taget talrige maalinger; at et $\mathrm{og}$ andet lidet krater $\mathrm{og}$ at udløsaabninger fra kratere kan være overseet, er vistnok saa, men ellers giver kartskizzen et korrekt billede af det hele $\mathrm{og}$ er ikke idealiseret. Hr. maler Knud Bergslien har udfort tegningen af kartet $\mathrm{g} g$ af kraterrækken.

Den vestlige del af den store Vatnajokull benævnes Skaptárjøkull elle Siðujøkull, og den kommer ind paa karteti dettes nordostre hjørne. Denne jøkul er ikke en enkelt smal arm, som fra en hoit liggende ismark gaar ned i et dalføre, men den er selv en stor, takket og mægtig ismark, der gaar skjoldformet ud mod et foranliggende, ikke særdeles kuperet landskab. Hvis de paa Gunnlaugssons kart angivne dimensioner er nogenlunde rigtige, saa har denne enorme jøkel en rand af 50 kilometers bredde, det vil sige, den er hele den vestlige del af Vatnajøkull. Den er imidlertid lidet eller rettere ikke undersøgt, og det gaar an at reise paa rent geografiske opdagelsesreiser i denne del af Island trods det, at landet nu har været beboet i over 1000 aar. Fra selve kraterrækken, ialfald fra de høiere kratere, sees jøkelen udmærket, og den synes ikke at ligge langt fra kraterne, skjønt erfaring viser, at man ofte bedrager sig med hensyn til bræernes afstand, da ismasserne, maaske paa grund af sin hvide farve, synes at ligge nærmere end de i virkeligheden gjor.

Ifra Skảptárjøkull kommer der tre elve, nemlig Túngná, som gaar mod vest og tilslut falder ud i pjorsá, - og med den faar vi her ikke mere at gjore - samt Skaptá og Hverfisfljót. Selve kilderne for disse er ikke nærmere undersøgte, men at de kommer fra jøkelen er sikkert nok; thi deres vand er grumset, som jøkelelvenes vand er. Efter et gammelt sagn skal de alle tre udspringe paa samme sted i jøkelen, og den oprindelige elv skal deles ved en stor klippe 
rgen i tre elve, men et saa mærkværdigt forhold trænger nok til yderligere bekræftelse. Skaptá synes at gjennemstromme en indsø, som ikke er afsat paa ældre karter, og som ikke er noiere kjendt. Denne so ligger, som man ser, nordligt for de nordostligste kratere i Lakis rakke og kan oines fra nogle af disse. At Skaptá kommer ud fra den, har jeg ikke seet, men da soen vel etsteds maa have aflob, saa er det yderst sandsynligt, at aføbet sker gjennem Skaptá. Den omstændighed, at Skaptá forer grumset jokelvand, behøver ikke at bevise, at den ikke gjennemstrommer nogen indsø; thi de andre jøkelelve paa Island, der gjennemstrømmer indsøer, bliver ingenlunde klare som elve, der kun fører bergvand $\mathrm{og}$ bygdevand. Saaledes har Hvitá i Biskupstúngur farvet jokelvand, nagtet den strømmer gjennem Hvitárvatn, ja selv den lange og dybe indso Lagarfjót er ikke lang og dyb nok til helt at klarne Fokulsá i Fljótsdal, saaledes som man kan se, at Genfersøen klarner Rhonen.

De to elve Hverfisfljót og Skaptá har forskjellig retning; den forste løber mod sydsydost. Skaptá derimod strommer forst mod sydvest, derpaa mod sydsydost og endelig soger den gjennem forskjellige arme ud i havet, dels ud i Kỉðafjót, dels tager den en ostlig retning ud i Skaptárós. Ved Hverfisfljót og Skaptá med dens tre retninger indesluttes et stykke land Sida, der har formen af et trapez, som bedst kan sees af kartet; og dette land var det, som udsattes mest ved udbrudet af Laki; thi ligesom elvene omslutter hin landstrækning, saaledes omslutter de ved udbrudet dannede lavastromme det samme land; den flydende lava fulgte de samme veie som det rindende vand, det vil sige de løb fornemmelig efter elvenes render, og ligesom hine to elve Skaptá og Hverfistljót har sine kilder og sine udløb nær hverandre, medens de er vidt adskilte i de midtre dele, saaledes ligger hine gigantiske lavastromme i sine midtre partier 30 kilometer og mere fra hverandre, medens de har havt sin kilde $\mathrm{i}$ den samme store spalte, og medens deres nederste rand ikke ligger fulde 10 kilometer fra hverandre.

Hin landstrækning, Siða, der næsten omkrandses af lavastrømmene, høiner sig mod nord, saa at gaardene sydligst kun ligger ca. 80 meter over havet (saaledes Horgsdalr 69 meter, indsoen Holtsló 79 meter); mod nord hæver landet sig temmelig hurtigt, saa at gaarden Eintínaháls ligger 221 meter o. h. Hoieste punkt paa overgangen mellem. Skaptárðalr og Holtsló er 307 meter, og tjeldet Kaldbakr er 715 meter (2279 fod høit). Længst mod nord naar fjeldet Blangur en høide, som vistnok ikke er maalt, men som kan anslaaes til omkring 900 meter. Nord for Blængur sænker landet sig igjen, og kraterne ligger i denne lavere egn, saa at man fra Blængur og omliggende fjelde, der naar høider paa 800 til 900 meter, kan se ned paa kraterne, der ligger nogle hundrede meter lavere, som senere omtalt. Disse høideforhold har været afgjørende for den vei, lavamasserne har taget under det udbrud, som vi her kommer til at beskjæeftige os med. Da der i syd for kraterne laa et hoit land, saa kunde lavamasserne ikke tage veien direkte mod syd i retning af havet, men de oversvømmede forsænkninger og dale i strækningen nord for Blængur og sogte ned igjennem dalforerne paa vestsiden og paa østsiden af det hoie land, først langs Skaptá, og senere langs Hverfisfljót, og ankomne paa det flade land foran dalforerne flød de udover, i betydelig afstand fra kilden.

Vest for Siða og Skaptá ligger en bygd, som heder Skaptártínga, der mod vest støder op till Mýrdalsjøkull, hvor en anden frygtelig vulkan, Katla, holder til. Ost for Skaptá ligger Fljótshverfi, der mod nord støder op til Skaptárjøkull eller Siðujøkull; i denne egn har der ogsaa været eruptioner, dels i Siðujokull fra en vulkan, som ikke er nærmere kjendt, dels har der været eruptioner $\mathrm{i}$ isen nordost for Fljótshverfi paa et sted, der benævnes Grímsvotn; men heller ikke denne vulkans beliggenhed er kjendt, og den hele egn er overhovedet lidet undersogt. Langs kysten paa den her omhandlede del af Island ligger der, som før berørt, fladt land, hvis beskaffenhed forandrer 
sig, alt eftersom der paa det nordenfor liggende hoie land er jokler eller ikke. Hvor der i hoiderne er jøkel, er der paa det lave land sand eller ørken. Er det hoie land fri for bræer, saa er det foranliggende land dyrkbart og forholdsvis frugtbart, hvis det ikke er oversvommet af yngre lava. Saaledes ligger foran Mýrdalsjokull, i hvis høieste dele Katla holder til, Mýrdalssandr, en ørkenagtig, lav strækning, gjennemstrommet af grumsede elve; foran det isfrie land i Skaptártúmga ligger det dyrkbare Alptaver, foran Siða Landbrot $o g$ Meðalland, $o g$ disse egne er frugtbare og beboede undtagen der, hvor lavastrommene fra Laki har lagt landet helt ode. Længer mod ost stoder man paa Skeiðarársandr, foran Skeiðarárjokull. Man kan altsaa i korthed sige, at der, hvor jokler og vulkaner arbeider i hoiderne, der lægges det foran liggende land ode ved sand eller ved lava; men hvor det lave land har faaet lov til at ligge $\mathrm{i}$ fred, kan det beboes.

Det vil af, hvad der ovenfor er sagt, og af kartet fremgaa, hvor mærkværdig begrændset denne egn omkring Sida er. Lava omgiver landet mod ost, nord og vest, og halvdelen af den skraanende sydside er begrændset af lava. Nordostligt ligger den store Vatnajøkull, og nordenfor lavaen $\mathrm{og}$ vest for jokellen komme store ode landstrakninger. Den sandede aabne kyst gjor, at havet ingen frerselsvei er for denne egns beboere, og de udveie, som er levnede, forer som berort baade mod ost og vest gjennem sten- og sandørkener uden græs og over talrige, farlige jokelelve.

- Palagonittuf og palagonitbreccie og konglomerat danner, saavidt iagttaget, overalt i denne egn det oprindelige faste land, igjennem hvilket gammel og ny lava er brudt op. Det er værd at bemærke, at selve Lakis spalte gaar gjennem tuf. Alle de vulkaner, som er kjendte paa Island, sætter op i tufformationen, ikke $\mathrm{i}$ den saakaldte basaltformation eller doleritformation.*) Palogonittuf og palagonitkonglomerat danner det faste land i Skaptártúnga, paa hele Siða og Fljótshverfi, og alle fjelde, Blængur, Varmárfell, Galti o. s. v., som rager op omkring kraterne, bestaar af tuf med basaltgange og ofte med basaltsoiler $\mathrm{i}$ hoiderne, og ligeledes alle fjelde nordligt for lavastrommen som Uxatindr o. s. v. Disse sidste fjelde er vistnok ikke noiagtigt undersogte, men palagonittuffens eiendommelig rødbrune farve og landets $\mathrm{og}$ fjeldenes hele konfiguration viser tydeligt nok, at det er et tuflandskab, som ligger foran os, nordvest for de af lavastrømme begravede strækninger.

I tufformationen sætter der meget hyppigt op gange af seileformet basalt. Disse gange er ikke afsat paa kartet, thi det vilde være et helt stort arbeide for sig selv at aflægge dem alle. De udbreder sig hyppigt til dækker, ligesom de paa forskjellig vis kiler sig ind mellem tuflagene. De forekommer hyppig i fjeldenes topper af den grund, at de har storre evne end tuffen til at modstaa den almindelige degradation, saaledes at fjeldene $i$ denne egn synes at skylde basaltsøilerne $i$ topperne sin nuværende høide, idet den tuf, som engang har udfyldt mellemrummene fra fjeld til fjeld, er fjernet ved forvitring, degradation, erosion o. s. v. Der kunde nævnes talrige exempler paa fjelde fra Islands palagonittufformation, i hvilke basaltsøiler optræder i høiderne. Paa Siða nær gaarden. Holt ligger saaledes Holtsborg med pragtfulde søiler i høiderne og palagonittuf i foden. Paa overgangen fra Skaptárdalr til Holtsl6, paa veien til kraterne fra Geirland langs elven Stjorn, i høiderne langs Hørgsá i Hørgságlúfr og flere steder sees vakre basaltsøiler, snart regelmæssige, snart vifteformet anordnede, snart i storre eller mindre uorden. I selve palagonittuffen ligger paa mange steder stene af basalt, der er i nogen grad tilrundede, og disse blokke bliver ikke sjeldén saa talrige, at tuffen gaar over til et konglomerat, hvori tuffen er bindemidlet.

Langs elvene, hvor disse har stærkt fald, er der stadigt udgravet erosionsleier, der underm

*) Om Islands geologiske bygning se „Om Islands Geologi“. Geograf. Tidsskrift. Kjøbenhavn 1882.

tiden dybe re Dalságlj dybde. reldre be da elven

kyst lige sig over ost til land, og som ma Islands nærmere

denne es rede af Paa det at Rober siger ha tallet $t i$ mere st den see lige gre mistet $k$ form. ældgaml 1783 o omkring rækken oppe i Uxatind viserne

angrivne over ga angiver. om lav: Skaptáe strækni paa beg 
derne

r det

tiden naar et betydeligt dyb, og som udmærker sig ved sin steilhed $o g$ vildhed; deslige gjel eller dybe render udgravede af elvene kalder Islændingerne „gljúfr . Nær Skaptárdalr ligger saaledes Dalságljúfi, hvor en forholdsvis liden elv har skaaret sig en dyb rende paa et par hundrede fods dybde. En storartet gljúfr er Hergságljúfr, ost for Kaldbakr langs Horgsá. Der har efter de ældre beskrivelser oiensynligt været lignende dybe render langs Skaptá, og maaske storre og dybere, da elven Skaptá er saameget storre end disse andre smaaelve.

Efter Istiden har denne del af Islands kyst ligesom vistnok den storste del af landets sydkyst ligget lavere, saa at havet er gaaet op til foden af Sida, der hvor landet nu begynder at hoine sig over det foranliggende lave Medalland og Landbrot. Rider man saaledes fra Hogrsdalr mod ost til gaarden Foss, saa har man tilvenstre palagonitklipper, der styrter brat ned mod det flade land, og disse klipper er $\mathrm{i}$ hoi grad forrevne og viser $\mathrm{i}$ det hele alle de spor af havets arbeide, som man iagttager paa steder, hvor den blode tuf gaar ud imod det aabne hav. Beviserne for at Islands sydkyst har staaet lavere er imidlertid af forskjellig art, og vi vil ikke her opholde os nærmere ved dem.

Tuffen med basaltgangene er, saavidt iagttaget, de eneste bergarter, ældre end istiden, i denne egn. Men foruden de yngre kratere og lavastromme er der talrige aldre, salaledes som allerede af Magnus Stephensen omtalt. Paa mange steder er der et utroligt antal smaa bitte kratere. Paa det flade land i Landbrot omkring Arnardringr optræder disse gamle kratere i saa stort antal, at Robert*) anslaar deres antal til mindst 2000. „Over et umaadeligt rum, der taber sig for oiet, siger han, iagttager man smaa kratere, der har tyve til tredive fods høide. Naar jeg anslaar antallet til mindst 2000, frygter jeg ikke for at gjøre mig skyldig i overdrivelse. Intet kan give en mere storartet forestilling om de vulkanske kræfter end denne egn, helt besaaet med kegler, naar den sees i nogen afstand. Imellem Holt og Kirkjubær langs nordsiden af Skaptás lavastrøms østlige gren har jeg iagttaget talrige gamle kratere af lignende form, indtil 20 fod høie; enkelte har mistet kraterformen, er græsklædte, sammensunkne, men mange har endnu bevaret sin eiendommelige form. Det slaar ikke feil, at den vestlige arm af Lakis lavastrom har flydt over talrige saadanne ældgamle kratere. Præsten Jón Steingrimsson beskriver saaledes, hvorledes den nye lavastrøm i 1783 oversvommede talrige smaa kratere østenfor og sondenfor Skál. I egnen oppe ved kraterne omkring Laki findes der paa opdukkende øer i lavastrommen ogsaa talrige kratere, ja selve kraterrækken eller ildlinien af 1783 gaar igjennem nogle gamle kratere. Ogsaa nogle andre steder midt oppe i patagonittuffen har jeg iagttaget kratere, saaledes paa ostsiden af Miklafell; ved foden af Uxatindr synes der ogsaa at ligge nogle kratere, hvilke jeg imidlertid kun har seet i afstand. Beviserne for en gammel vulkansk virksomhed $\mathrm{i}$ disse egne ere tydelige nok.

Ogsaa af gamle lavastromme findes der levninger, og disse lavastrækninger er paa kartet angivne med en særskilt farve. Selve lavastrommen af 1783 har ialfald $\mathrm{i}$ den nederste del flydt over gammelt hraun eller gammel lava, hvilket Magnus Stephensen og Sveinn Pálsson udtrykkeligen angiver. Ogsaa langs Skaptás rende har der ligget en ældgammel lavastrøm; thi Stephensen siger om lavastrommen af 1783 , at den den 12 te juni løb med stærk fart for det meste samlet ned ad Skaptáens rende og udbredede den sig hist $\mathrm{og}$ her over de gamle, ved siderne forekommende lavastrækninger. Jón Steingrimsson siger i sit skrift »Um Skaptáreldinn «, at der var lava (brunahraun) paa begge sider af Skaptá. Endelig fortæller Sveinn Pálsson, at ifølge kyndige folks beretning be-

*) Voyage en Island et en Groenland par Gaimard. Mineralogie et géologie par E. Robert pag. 226 
stod de nu af udbrudet fyldte Skaptár- og Hverfisfljóts gljufere af forbrændte klipper for 1783, og han siger, at man kunde forlangt, at Stephensen paa kartet skulde angivet de gamle hraun ved Leiðvollr, Steinsmýri, Arnardrángr o. s. v., saa at man kunde se, hvorvidt denne vulkans oversvømmelse var gaaet over den forrige eller var bleven indenfor sammes grændser. Paa Meðalland, der hvor nu den nye lava ligger, var der før gamle hraun, af hvilke et hed Botnahraun og et Steinsmýrarhraun, ligesaa var der hraun mellem Siða og Skaptártánga, hvilket imidlertid blev oversvømmet 16 de juni 1783. Gaarden Hólmar og Hólmasel, som blev oversvømmet, stod nær gamle hraun. Naar man har passeret Mýrdalssandr, og for man naar Leirá, forekommer der ogsaa gammelt hraun, og dette samt de af Pálsson angivne steder er paa kartet mærket som gammel lava. Men hvorvidt der, saaledes som Pálsson synes at antage, har strakt sig sammenhængende ældre lavamasser helt oppe ifra omegnen af Laki og ned gjennem Hverfisfljot og Skaptá til Meðalland, tør jeg ikke afgjøre. Men de talrige gamle kratere oppe i vildmarken og de gamle hraun i bygden synes at antyde noget saadant.

Videre angiver Pálsson lava ved Núpar og Raudaberg, hvor man tydeligt ser, at gammel lava har flydt $\mathrm{i}$ to arme fra fjeldene, nemlig ned ad Djupás og Brunnás render. Det forste hraun i Djupás rende har jeg seet; det var en lava, som meget ligner lavaen fra 1783, men den røbede sin æelde blandt andet derved, at blærerummene begyndte at fyldes med grønjord.

Foran den sydlige del af Skaptárhraun i Meðalland og Álptaver har jeg ikke reist, men naar man sammenholder Pálssons, Roberts og Paijkuls iagttagelser med mine egne fra omegnen af Leirá, og naar man derhos bemærker navne paa enkelte gaarde som Underhraun paa Meðalland, Hraunbar og Hraungerdi i Álptaver, hvilke navne er gamle og antyder tilstedeværelsen af lava, saa synes alt dette at vise, at der foran og under den nye lava paa Meðalland ligger gammelt hraun, som paa kartet angivet. At saa er tilfælde angiver endog Sveinn Pálsson udtrykkelig, idet han siger, at der løber en uafbrudt lava langs fjeldene, østerhen fra Kúðafjót til Fljótshvérfi, og han antager det for rimeligt, at denne lave har flydt ud et steds i nærheden af Lakis kraterrække ned af elvens render og ligesom nu til det flade land, hvor den for 1783 var sunket ned og hensmuldret.

Endelig optræder det, Islændingen kalder sandr«, ode sand og stensletter, over store strækninger foran jøkullen og i de lavere dele af den her omhandlede egn. Sydvestligst paa kartet kommer ind en del af Mýrdalssandr, der oversvømmes ved jøkulhlaup, naar Katla i Mýrdalsjøkull har udbrud. Det er som for nævnt golde strækninger af los sten og sand. Langs havet og ved Skaptárós ligger ogsaa betydelige sandstrækninger, som gjennemskjæres af de stadigt vexlende arme af elvene, som her danner ufrugtbare deltaer.

Naar saa endelig Skaptárjøkullens ismasser er nævnt, saa er her opregnet de i denne egn forekommende gamle og unge bergarter.

- Af ældre beskrivelser over Lakis kratere og deres udbrud i 1783 er der følgende:

Magnus Stephensen, Kort Beskrivelse over den nye Vulkans Ildsprudning i Vester-SkaptefjeldsSyssel paa Island i Aaret 1783. Kbh. 1785.

S. M. Holm, Om Fordbranden paa Island i 1783. Kbh. 1784.

Fón Steingrimsson, Um Skaptáreldinn dateret Prestbakki i 1788. Dette Skrift findes saavidt mig bekjendt kun trykt i Markís Loptssons bog: Rit um jardelda á Islandi. Reykjavik 1880.

Sueinn Pálsson, Tillag til Beskrivelserne over den Volcan, der brandte i Skaptafells Syssel Aar 1783, samlet ved en Reise i Egnen Aar 1793 og 94.

Dette sidste arbeide har ligget som manuskript i Kjøbenhavn, indtil jeg trykte det af i 
Thuristforeningens aarbog" for 1881 under titel 1slandingen Sveinn Pálssons beskrivelser af islandske vulkaner og brceer.

Magnus Stephensens arbeide er det vigtigste kildeskrift om selve udbrudet. Da efterretningen om udbrudet kom til Kjøbenhavn, blev der høsten 1783 sendt et fartøi til Island, og Stephensen fulgte med dette skib specielt for at indhente oplysninger om vulkanens odelæggelser. Skjønt han seilede afsted den 11te oktober 1783, kom han først 16de april 1784 til Island, da vedholdende storme om høsten hindrede reisen, saa at skibet efter tre møisommelige forsøg blev nødt til tre gange at seile tilbage til Norge, og det maatte tilslut overvintre der.

Stephensen kom altsaa til Island aaret efter udbrudet; da var lavastrømmen endnu saa hed, at han ikke kunde gaa over den, og det lykkedes ham derfor ikke at naa frem til selve kraterne. Han iagttog fra fjeldet Blængur, der, som man ser af kartet, er skilt fra kraterne ved en lavastrøm paa 1 til 2 kilometers bredde, et fjeld, om hvilket han siger: "Man kan sikkert tro, at det lave rundladne Bjerg, som ligger i Nord for Blæng og nordligst i Lavastrækningen lader sig til Syne, er denne Vulkans Kilde, eller Opsprudningsstedet selv«. Derimod tor han ikke afgjøre, om dette antagne udbrudsted for har været et bjerg, eller om det er opdynget af pimpsten og andre udkastede materier. Han afsætter paa det kart, der ledsager hans beskrivelse, ét udbrudssted eller én vulkan. Det bjerg, han har seet, maa efter beliggenheden have været fjeldet Laki, der er et ældre fjeld bestaaende af tuf, men igjennem dette gaar den omtrent 20 kilometer lange spalte eller ildlinie, saaledes som vil sees af karterne og af den følgende beskrivelse.

I et senere skrift »Island $i$ det attende Aarhundrede", Kbh. 1808 angiver imidlertid Magnus Stephensen, at udbrudsstedet ligger i Skaptárjøkull, og under det feilagtige navn, Skaptárjøkullens udbrud, omtales denne eruption i Lyells: Principles of Geology og i andre geologiske haandbøger.

S. M. Holms Skrift „Om Jordbranden paa Island i 1783« er ikke baseret paa egne iagttagelser, men er sammensat efter beretninger fra Island. Skriftet har mange feil og maa idethele benyttes med stor kritik.

Jón Steingrimsson, der har forfattet skriftet »Um Skaptáreldinn«, var provst paa Prestbakki $\circ \mathrm{g}$ boede saaledes midt $\mathrm{i}$ den af lavastrømme oversvømmede egn, $\mathrm{og}$ hans arbeide har naturligvis ikke liden betydning, da forfatteren var øienvidne til udbrudet.

Sveinn Pálsson var den første, som naaede frem til selve udbrudsstedet, og som paaviste en del af selve kraterne. Men siden hans tid har ingen beskrevet dem. Heller ikke han giver vulkanen noget særegent navn, men kalder den 1783 aars vulkan.

Den islandske geolog Th. Thoroddsen, der har følt nødvendigheden af et navn, kalder i sin »Oversigt over de islandske Vulkaners Historie 1882 « udbrudsstedet Varmárdalr og bruger dette som navn for vulkanen. I et senere tillæg oplyser han imidlertid om, at de omkringboende ikke kjender dette navn, og siger, at man maaske ligesaa godt kunde kalde dem Skaptá-renden vulkaner. Kraterne ligger imidlertid ikke i Skaptárenden, om end lavastrømmen har udfyldt en stor del af Skaptás rende.

Hvis man imidlertid vil have et kort og godt navn i overensstemmelse med de mest bekjendte andre islandske vulkaners navne som Hekla, Leirhnúkr, Krafla o. s. v., da er navnet Laki selvsagt. Thi ligesom Heklas og Leirhnúkr tufrygge er gjennemsatte af spalter, efter hvilke kraterne ligger, saaledes er Lakis tufryg ogsaa delvis spaltet, og kraterne ligger paa begge sider af dette fjeld efter spalten. Navnet Laki er derhos brugt og vel kjendt af de folk, som af og til færdes i vildmarkerne her. 
Ved den folgende beskrivelse maa vi erindre, at den beboede del af denne egn ligger 20 til 30 kilometer ifra selve kraterne, hvis beliggenhed ikke engang var noiagtig kjendt. Lavaens gang og udbredelse oppe i egnen omkring Laki er ikke bekjendt efter øienvidners beretning, ja lavaens udstrækning oppe i fjeldet er endnu den dag idag ikke nøiagtig undersøgt.

- I mai 1783 var der udbrud $i$ havet udenfor Reykjanes, idet man fra skibe iagttog rog og fandt havet dækket af pimpsten i 20 til 30 miles afstand fra udbrudsstedet, saa at skibene havde vanskeligt for at komme frem. En ny o bestaaende af temmelig høie klipper og af en ndstrækning, der angives forskjelligt fra 1 til $1 / 3$ mils $\mathrm{i}$ omkreds, havde dannet sig ude $\mathrm{i}$ havet. Øen, der kaldtes $N y$, forsvandt snart.

- Som varsler for udbrudet fra Lakis kraterne angiver Jón Steingrimsson forskjellige frenomener, som dog sikkerligen intet har med det kommende udbrud at gjore, som at lam fødtes med rovfugleklør, at vanskabte kalve kom til verden osv. Videre fortæller han, at lyd hørtes i jorden og lig klokkelyd hørtes i luften, at tolk levede i stor overdaadighed, at drukkenskab og tobaksforbrug var saa stor, at der paa et aar brugtes paa Siða 4000 fisk (93 rigsdaler 73 skilling) til gjæstebud og drik, at præster neppe kunde forrette gudstjenesten uden brændevin o. s. v.

- „Et yndigt foraar 1783 afloste en i Island usædvanlig mild vinter", siger Magnus Stephensen. Klart, stille og varmt veir med solskin afvexlede bestandig med sagte blæsende sydlige vinde og imellem frugtbargjorende regn; tidlig saa man markerne iforte den gronne og vellugtende foraarsdragt og i mai maaned smykkede med mange slags blomster $\mathrm{i}$ den frodigste væxt; man spaaede sig af kreaturerne, som efter en saa mild vinter og foraar, var fede og $\mathrm{i}$ den bedste stand, den allerstørste nytte, og man glædede sig $\mathrm{i}$ haab om en forventende frugtbar sommer og rigelig høst. Men denne glæde endtes med mai maaned

I slutningen af mai maaned 1783 havde man iagttaget en tynd blaagtig rog eller taage, som man undertiden saa svæve over jorden; saadan taage kalder Islændingerne "mistur, $o$ o den antages at være forbud paa vulkanske udbrud.

Den folgende beskrivelse bor fólges paa kartet, hvor man vil finde de fleste, men ikke alle de nævnte steder afsatte.

Den 1ste juni bemærkedes stærke jordskjælv over hele Skaptafells syssel, og de blev stærkere $\mathrm{og}$ stærkere dag for dag især om morgenen $\mathrm{og}$ om aftenen indtil den 8de juni, som var første pintsedag. Da trak der kl. 9 om formiddagen op fra nord og tilsidst over hele Siða en mork $o g$ sort banke; sydligst fra Landbrot saa man mangfoldige rogstotter stige op af de vilde fjeldstrækninger nordenfor, hvilke samlede sig til denne sorte banke. Det blev mørkere og mørkere paa Siða, og da banken stod ret over, begyndte der at falde aske og sand til en tommes høide; asken havde et udseende som aske efter udbrændte stenkul og ledsagedes af en graa, glindsende, haaragtig materie, siges der. Sydlig vind holdt asken tilbage denne og den folgende dag; men jordskjælv med tordenslag, underjordisk knald og raslen forøgedes stadig; denne dag og længe senere hørte man langt inde i fjeldene mod nord en stærk bulder, ligesom af mange i ét samlede vandfald eller i det store det samme som lyden af en stor kjedel, der koger over.

Jón Steingrimsson beretter saaledes om udbrudets begyndelse: Den 8de juni, som var pintsedag, med det vakreste, klareste veir kom der op nordenfor bygdefjeldene en sort skybanke, som i kort tid udbredte sig over Siða og Fljotshverfi eller over en del af samme, og det saa tæt, at der blev morkt i husene, og spor saaes paa jorden af et støv lig stenkulsaske, men i Skaptártúnga blev det strax en sort blød masse som blæk. Det var kl. 8 om morgenen, at ilden kom op. Syd-

gstlig paa de skjælv. regn at

strækni

forstær paa de

1881 a og udts $\operatorname{man}$ fo

9de ju juni, os

naar si der i fi

Skaptá 400 til lavastre paa be indeslu ned $\mathrm{i}$ skjalv

En mo graa h: dels so aldrig nordent bragen græssel skulde

dog ud foraars: klynge om aft svomm havde 
ostlig vind forte banken nordover den dag, saa at jeg som andre prester kunde forrette gudstjenesten paa denne hoitidsdag, men denne glede foraudredes snart til sorg. Om natten indtraf stierke jordskjæelv. Den 9de var det klart; da havede skybanken sig strerkt, og om kielden kom der nsende regn af den.

Den 10de juni saa man forst tydeligt adskilte ildstotter opstige inde $\mathrm{i}$ den nordlige fjeldstrekning; sandskyen steg for hver dag hoiere, og jordskjielv med starke knald og tordenslag forstrerkedes dagligt. Demne dag faldt der regn, som voldte en nesten utaalelig svie, hror den faldt paa den bare hud, og somme draber frembragte huller pata hoimalebladene.

Skaptrí, hvis bredde paa den tid var 70 farne paa fiergestedet, og hvis vandmengde jeg $\mathrm{i}$ 1881 anslog til 40 kubimeter vand i sekundet - ved Skaptárdalr —, forsvandt til alles formundring og udtorredes ganske paa et dogn den 11te juni, saa at man kunde gaa over paa de steder, hvor man for med besvier satte over $i$ baarle.

Efter .Jon Steinngrimsson udtorrede Skaptí helt den 10de juni, medens den allerede den 9de juni begyndte at minke. Magmus Stephensen angiver, at floden voxede starkt 9de og 10 de juni, og udtorrede den 11te eller dagen efter.

Den 11te kom snedrex, som ridt om odelagde graesset. Det kom fra skybanken, ligesom naar sneen falder tykkest on vinteren; i Skaptártunga var snefaldet endmu voldsommere, og den lat der i fem dage. Den 12 te var det klart og sydlig vind.

Den dag kom en skrekkelig ildstrom ligesom et brusende hav med sterkeste fart efter Skaptás rende; denne, der gik giennem dỵbe dale og meget store bergklofter, var paa mange steder 400 til 500, ja over 600 fod dyb, og, siges der, indtil 200 fod bred, men ikke desto mindre har lavastrommen udfyldt hele renden og paa sine steder oversvonmet et temmelig stort stykke land paa begge sider; $\operatorname{dog}$ ser man endnu para nogle fala steder de hoieste blaudt de bjergspidser, der indesluttede hin gamle rende, rage op af den nye lava. Der hror strommen faldt ud over firsene ned i gljufret eller renden, var der saa strerke skrald som af de voldsomste tordenslag, sai at alt skjaly og rystede.

De redsler, der ledsagede dette forste udbrud, er det umuligt fuldkommen at beskrive. En mork og gruelig banke trak op fra n. vo og udspredte en mengde aske, sand, ssvordstor og den graa hauragtige materie, en forfixdelig stinkende og kvælende rog omhyllede jorden og opslugte tildels solens velgjorende straaler; sjelden var den at se gjennem den tykke rog og svovlede taage og aldrig anderledes end som en blodrosd, dunkel klode, idelige jordskjely og stod, utallige ildstotter nordenfor, en forskrekkelig frembrusende ildstrom langs ad Skaptás rende, ubeskrivelig knagen og bragen i luften, svare underjordiske knald, raslen og bulder fra fjeldene og uophorlig lynen med de gresseligste tordenskiald satte den storste skrek i menneskene, som trenkte, at himmel og jord skulde forgaia.

Ildstrommen lob nu, for det meste samlet, med stark fart ned ad Skaptís rende, idet den dog udbredte sig noget hist og her over de gamle, ved siderne forekommende lavastromme; iswer foraarsagede det en strerk bulder og lydelige slag, naar de store, glodende lavastykker styrtede klyngevis ned i de i Skaptís rende opdemmede vandpytter. Paa én eneste dag valr lavastrommen om aftenen den 12 te allerede loben frem til gaarden Á ved Skálarfjall paa Sida, hror den oversvommede huse, hjemmemarker og enge samt det meste af udmarkerne, ligesom strommen ogsala havde beskadiget gatarden Büland og odelagt dens to husmandspladse Suartignitpr og Linlanes; des- 
uden havde ilden paa den vestlige side allerede beskadiget gaardene Svinadalr og Hvamir samt Skaptárdalr paa den ostlige.

Efter Steingrimsson odelagdes gaardene $\mathrm{A}$ og Nes den 16de juni. Efter samme forfatter var det den 13de lilar luft; der hortes svære knald og larm bag fjeldene; der indtraf stærke jordskjælv med forferdeligt brag som en fossedur, hvilket holdt ved i netter efter. Skybanken var da saia stor, at den saaes over hele landet. Solen var nu rod som en ildkugle, men maanen var som blod at se.

Man havde ventet, at den uhyre masse lava, der flod som smeltet metal med strerk fart efter Skaptás rende, nu med engang skulde styrte frem over det foran dalen liggende flade land. Meu ilden standsedes den folgende dag, den 13 de juni, af et stort vandsvalg (se kartet) som efter gamle folks beretning skal have været etsteds mellem $\mathrm{A}$ og Skaptárdalr, meu som nu delvis var opfyldt med sand fra Skaptá. Dette vandsvælg opslugte en stor del af lavaen, hvilken i nogle dage styrtede ned i samme med megen raslen og bulder ligesom af en fos eller sluse, hvor vandet falder med strerk fart. Da dette svælg var opfyldt, og da lavaen, som idelig fik tilforsel ved nye masser fra udbrudsstedet, var opdynget til en betydelig høide i dalen mellem Skaptártánga og Á, saa brod ildstrømmen længer frem over bygden. Forskrækkelig kuald og raslen som af de storste stenskred, hvorved hele egnen skjælvede og brvede, med stærke og stadige lyn og svære tordenskrald forstyrrede alles ro og hvile natten mellem den 14de og 15̃de juni; den glodende lava oversvommede om natten gaarden Nes paa Skaptártínga samt alle deres gresmarker og landstræekninger, deriblandt mange bevoxede med kratskov imellem denne gaard og Skálarstapi paa Siða. Herfra lob en arm østover forbi gaarden Skál og lige torbi gaarden Holt, hvor deu standsede nogle dage, men opbrændte paa veien skovstrækningen Brandaland, som tilhørte Kirkjubæjar Klaustr.

Den 14de juni var det stille; da drev der store mæugder sand omkring overalt; det regnede ned med dotter eller haar af lengde og tykkelse som mundhatrene paa en sel, og dette fortes vidt over landet. Om kvælden kom der osende regn af morkeblaa fiuve. Det var saa daarlig luft, at brystsyge folk taalte neppe at drage aanden og var ner ved at falde $\mathrm{i}$ afmagt. Alle sommerens fugle flyttede nu bort herfra, siger Steingrimsson. Deres ag blev uspiselig paa grund af svovlsmag, orreter fandtes døde vidt omkring. Spurve og erler blev der en tid, men fandtes saa dode i flokkevis. Denne vaar havde græsvexten været $\mathrm{i}$ god forfatning, og nu stod markerne rundt omkring i fuld blomst; men det visnede nu overalt, saa der saaes ikke grøn farve paa jorden. Pimpsten og sand rakede folk bort med river, saa nautene kunde faa beite. Nogle skar græsset af og vaskede det, skjont til liden nytte. Lordagen for pintsedag, altsaa dagen for udbrudet, blev der hos Steingrimsson baaret ind 13 fjorðungsskjoler melk (omtrent 130 liter), men neste lordag 12 merkur (omtrent 6 liter). Den 15 de var vinden sydøstlig, og den dag og natten derefter var der stærke jordskjælv.

Den 16de var det samme vindretning; da kom der en frygtelig ildstrøm frem af glufret, saa at det syntes fyldt af samme, og da odelagdes klosterjordene A og Nes. Da odelagdes hele hraunet mellem Skaptártánga og Siða, som var en af de bedste hager for beiting. Dertil horte Brandaland, som var helt bevoxet med skog og omsvommet af Skaptás grene. Da ødelagdes ligeledes de saakaldte Skílar- og Holtsgaarde. En anden gren af ildstrómmen stevnede frem paa Meðalland, hvor forst Botnar- og Steinsmýrarhraun laa foran. Nordenfor de nærmeste bygdelag paa Siða, var der nu saadan brag, larm, ild og rog, at folk antog, at bygden ikke længer var uden fare. Da drog 3 bonder op paa Kaldbakr og saa, at i Úlfursdalur var der 22 ildsøiler.

hoviled ilden ho randt $\mathrm{s}$ iagttage men $\mathrm{i} \epsilon$ hængen modstoc

sydvest kommer og lige diske $\mathrm{h}$ vendige andre ilden, ind $\mathrm{i}$ i ét me saa at, siden $\mathrm{p}$ denne 1 af ildflo ellers $n$ i luften maade trænge 120 til uhyre gione fo

af tidlig ning af fira forh omsmelt men i sten, sy

frem in som bo telig ilc ikke sy at alt s 
Den 17 de juni var det vakkert veir, og Steingrimsson drog da til gaarden Skál for at se; hvorledes det gik med ildstrommen. Han siger, at han saa et gammelt hraubrelte, under hvilket ilden holdt paa at bryde sig frem med saadan voldsomhed, at det var et under, fordi hele hraunet randt sammen som talg. Sveinn Pálsson beretter, at kyndige folk, men isæer bonden paa Skál, havde iagttaget, at alle tider ved et udflod fra vulkankilden randt lavaen ei ovenpaa det gamle storknede, men i et med samme, og blev, ved at smelte det meste deraf paany, til en uadskillelig eller sammenhængende flod. Hvor den nye lava ikke kunde skyde henunder eller umiddelbart berore den gamle, modstod denne al smeltning.

¿I de tre paafolgende dage indtil den $18 d e$ juni udbredte ilden sig saa sagte mod syd og sydvest fia Skál over de xldre lavastrækninger, « beretter Stephensen. „Her opfyldte den' alle forekommende, endog de skjulte indvendige hulheder, hvorved den gamle lava blev betydelig forhoiet og ligesom opsvulmede; men dette gik ei af uden en stærk hvinen eller susen $i$ de underjordiske huler (ligesom man kunde hore mange $\mathrm{i}$ et forsamlede blæsebælge), forararsaget ved den indvendige luft, som, forjaget af den i disse huler nedstyrtende ildstrom, maatte med magt bane sig vei til andre steder, endog ud gjennem de snævreste aabninger. Sand og muldjord blev ikkun sveden i ilden, og paa den almindelige graasten virkede den ikke synderlig; derimod trængte den sig ned og ind $\mathrm{i}$ de mindste huller og porer af den gamle lava, som derved smeltedes paany og flod saaledes i et med den ny; ja den tiendtes endog ligesom af sig selv, ligesom naar der gaar ild i en skov, saa at, hvor et stykke gammel lava var smeltet, blev det tilstodende ligeledes anstukket derved og siden paa samme maade, det ene af det ovrige, ved det andet. Endelig er det mærkeligt: at ved denne lavaens omsmeltning blev den overste skorpe $\mathrm{i}$ dagen usmeltet, saa at den kunde trækkes ud af ildfloden i hele store stykker og saa ud som sinner eller slagg af metal. Ildfloden grov sig da ellers noget ned i jorden og lob saaledes frem, kastende den overliggende jordskorpe enten hoit op i luften eller og til siderne og brændte siden i rene, stille luer. Hvor ildfloden havde par denne maade undergravet hoie og bakker, igjennem hvilke de hede dunster fra grunden ikke let kunde trænge eller faa udvei, der opkastede disse i luften med storste magt store hoie og klipper fra en 120 til 180 fods hojde med de sværeste knalde og dundren. Man forestille sig alcne, hvad en uhyre masse, opbrukket med saadan en voldsomhed og opkastet til en saa betydelig hoide, maa gjore for en larm, naar den igjen med accelereret hastighed falder ned paa jorden. *

Det er uvist, om den her omtalte smeltning af pgammel lava er at forstan som smeltning af tidligere lava fra dette samme udbrud med en endnu meget hoi temperatur, eller som omsmeltning af ældgammel, helt afkjolet lava. Vistnok var her langs Skaptá og foran Siða "gammel lava fira forhistorisk tid, men at den nye lava, efterat have flydt 20 til 30 kilometer, endnu skulde kunne omsmelte helt afkjolet lava, synes noget stærkt. At derimod den paa overfladen temmelig af'kjolede, men $\mathrm{i}$ de indre dele endnu meget varme lava omsmeltedes ved beroring med de nye tillob af smeltet sten, synes ikke urimeligt.

Den 18de var det nordlig bris. Da.steg »ildsluen saa hoit, at fra Úlfarsdalr naaede den frem imellem Lambatınga, som ligger ved vestre ende af Kaldbakr, og Geirlandshraun. De bonder, som boede i Varmsel, 1 mils vei nordenfor Siða, tog da flugten sydover til bygden.

Den 19de juni (efter Steingrimsson) eller den 18de (efter Stephensen) kom der en ny frygtelig ildstrom med-jordskjæly og tordenslag efter Skaptás rende, saa at bonderne paa Skaptárdalr ikke syntes der var varendes læenger og flyttede derfra. Den dag kom der saa stærke tordenskrald, at alt skjalv og rystede. Steingrimsson gik da med sine ledsagere hen til glufret, og der gik da 
ildflommen frem med saa stor fart, som naar vandmasser farer afsted. Nidt i den flod aaser og bjerge, som naar storhvalerne svommer paa havet, og naar bjergene stodte til hverandre eller de kom imod nogensteds, blev der overmate store ildynister.

Hvor Skaptís rende ikke for var helt opfyldt, der oversteg nu ved udbrudet den 18 de eller 19de juni en syselig ildstrom det overste af de hoie og steile klipper, som indesluttede renden. Strommen lob med stzerkeste fart fremover de forhen odelagte strekninger, hvor lavaen ved de yderste kanter allerede var bleven nogeulunde afkjolet og fast.

Midt i lavastrommen saa man svomme store glodende klipper, som demne havde revet med sig; en forfierdelig tyk og hvid damp opstod af de paa begge sider af elven opdzemmede floder, som her var i det heftigste kog; dette kogende vand gjorde adskillig skade paa markerne, især paa gaardene. Hrammo og Svínadalr i Skaptártúnga, ligesom en kratskoy paa den ostlige side, tilhorende Skaptárdalr, blex oversvommet af det hede vand og odelagt.

Ildstrommen gik videre frem den 19de juni, idet den delte sig i to arme, hvoraf den ene lob med samme sticke fart som foregaaende dag lige mod syd langs efter elven Melkvisl og frem over Medalland; den anden arm gik mod ost langs Siða, hvor den odelagde egnen omkring Skálarstapi og træengte herfra med utrolig hastighed lige op til Skálarfjall. Nen da fjeldet her hiudrede strommens videre udbredelse mod nord, saa voxte deune betydeligt $\mathrm{i}$ hojde og trængte stærkt ind paa fjeldet, saa at den oprullede det hele gronsver par de modstacnde bakker, som om det var en pakke klede. Om aftenen var denne strom ikke mere end 120 fod fra kirken paa Skál, da beboerne flygtede derfra. Strerke og idelige jordskjæely fortsatte, skjont de var sagtnet meget siden den 12te juni. Dagen efter lob den arm af ilden lige frem til gaarden Holt og oversvommede den hele strækning mellem denne gaard og Skál. Den arm, som lob frem mod syd langs Nielkvisl, gik paa begge sider langt ndenfor elveleiet.

Gaarden Skál stod længst inde i den dal eller skaal, hvoraf gaarden har navn; og denne dal havde lavastrommen sperret. Da der nu faldt osende regn den 21de juni eller dagen efter, saa blev der flom i brekkene para begge sider af gaarden, og det i dalen ved lavaen opdiemmede vand oversvommede gaarden Skál med kirken og husene. Steingrimsson beretter, at folkene flygtede op i bakkerne og levede der i udhuse og telte. Men da det var regn, forte de kjorene ind i fjoset. Men vandet roxede sala hurtigt, for man kunde sikre sig, at nesten alt kom under vand, kirken, gaarden og fjoset, saa at folk maatte tage sig til at rive taget op og drage kjorene med handerne op gjennem taget. Dette vand var allerede om morgenen den 22 de i sterk kog.

Medens vandflommen odelagde Skál, udbredte den vestlige arm af strommen sig med starkeste fart længer osterefter over elven Steinsmýrarfjót og ligetil præstegaarden Hólnasel, som den paafolgende nat blev oversvommet af lava tilligemed kirken. Samme skjæbne havde gaarden Hólmar.

*) Steingrimsson beretter følgende: „Paa det vand, som flød over gaarden, kom graasurte fugle, som kaldes „urtir". Fugle lig disse er blevne seet i Reykjahver i Ølfus og andre steder. Disse fugle dukkede $\mathrm{i}$ det. kogende rand, der hvor det boblede mest. Alle folk saa dette, men aldrig kom bønderne fuglene saa nar, at de kunde faa skyde dem. Det var sandfærdige mænd med et godt rygte, som saa dette." Mrærkvardigt nok berettes der $\mathrm{i}$ skrifter fra forrige aarhundrede paa flere steder om fugle, som svømmede i kogende kilder. De kaldes urtir eller hverafuglar. Olavsen og Povelsen, der dog ikke selv har seet dem, beskriver dem efter en troværdig mands udsagn saaledes: „1)e er af skabning og strrrelse som en liden and, samt mørkebrune af farve over hele legemet, undtagen at der sees en kjendelig hvid ring omkring ginene".

Den:-

odelag

graitrde fra de vatuin

ogr mal opdien mede

gaarde

jokull,

bag fij

Tinda

$29 \mathrm{de}$

ovenf:

krog i

Svarti

gik la

frygtel

som gi

andre

Den 1

husene

ødelag

hror

Der $\mathrm{v}$

kom

et lue

dremm

den $\mathrm{H}$

sand

rumme

sort,

fortes

over 1

nresten

Ildstre

Den 2 
Den 21 de juni brendte den nye kirke paa Hólmasel med alt tilbehor. Paa kartet er de nu helt odelagte gaarde Hómasel, Hómar og Botnar afsatte paa det sted, hwor de $\mathrm{i}$ sin tid laa.

Den 22de juni fortsatte strommen sit lob langs efter randen af Steinsmýrarfljót og tret til gaarden Efri-Steinsmýri, hvis narker den beskadigede; men her boiede ildtoden at og lob mod syd fra dette sted forbi gaarden Sydri-Steinsmýri og standsede omtrent 1800 fod fra det nordligste vaaningshus.

Strommen udbredte sig ogsaa mod vest over gaardene Sydri- og Efri-Fljótur med deres huse og marker. Gaarden Hnausar sattes under vand, derved at elvene Steinsmýrarfljót og Fedgakvisl opdaemmedes. Derefter nate lavastrommen de paa kartet angivne graendser, idet den oversvommede gaarden Botnar og marker mellem elven Lamdí og gaatuden Hnausar.

Den 25de juni var hraunet paa Meðalland saa hoit, at Jón Steingrimsson fira en kiket ovenfor gaarden Efri-Steinsmýri netop kunde se spidsen af fjeldet Hafisey paa sanden sydost for Mýrdalsjølkull, men da hraunet var sunket fuldkommen sammen, kunde han se fjeldet fuldstendigt til sanden.

Den 26de var det efter Steingrimsson sydostlig vind. Der var da et saa voldsomt udbrud bag fjeldene, at vluen gik igjennem skybanken, saa at gnisterne af den kom vest til porsmork og Tindafjallajokull orenfor Fljotshlíd, saa at folk der vest troede at ild var konmet op der. Den 29de juni var det tyk luft og vestlig vind. Da kom der for tredie gang et forfierdeligt udbrud oveufra, saa at mellem Skaptártínga og Árfjall blev der paany en luende ildstrom, som fyldte enhver krog i og udenfor glufret ovenfor Buland. Da odelagdes baade slaattemarker og hager horende til Svartignúpr, og ligesaa odelagdes Litlanes, som var en plads under Búland, ligesaa Núpar. Dar gik lavaen ind i husdoren i Hvammr i Skaptártúnga. Den 30te juni var det vakkert veir, men frygtelige jordskjelv. Ildstrommen kom i tre grene ud af glufret. En gik vestover ud i den elv, som gik fra Skaptá ved Skaptártínga og randt ud i Kádafljot mellem Hraun og Leidvollr. De to andre gik mod ost; den sydlige stevnede mod Landbrot, den overste mod ost langs Sidalygden. Den 1ste juli gik denne ildstrom efter Skaptás gamle rende og kom den folgende dag til kirken og husene paa Skál, der for var blevne kogte, og brendte op kirken og den velbyggede gaard. Der ødelagdes et vakkert sted i Holtsland, som kaldtes Holtsdalr, og som var meget rigt paa grres.

Sydost for Skál var der jevn mark med gamle gresbevoxede smakkratere langt syd, der hvor nu hraunet ligger. Dette var det vakreste sletteland paa hele Sioa og kaldtes Fagraland. Der var en bred vei vestenfor Skíl, og den kaldtes Messugotur. If de ovenfor omtalte kratere kom der forst lue op i hvert enkelt for sig, og saa forplantede den sig til det neste, indtil alt blev et luende baal. Da floi klipper og store stene op i luften med forfierdelig larm og ild. Holtsá dremmedes op, og dalen fyldtes med vand. Saa lob ildstrommen over alfarveien og brendte gaarden Holt op. Derefter gik den ost langs bakkerne og demmede for Fjardará, saa der lob vand og sand over gaarden Heidis enge. Fra den bte til den 12te juli holdt strommen paa at fylde hele rummet mellem Skálarstapi og Heidarháls. Den 9de drev aske over hele Siða, saa jorden blev sort, og den 10de var det samme veir, men den 11te og 12 te var det strid regn, san at asken fortes afsted, saa at man igjen sa jorden.

Ildstrommen gik den 13de efter Skaptás leie ovenfor Stapafoss, og den 14de gik lavaen udover nevnte fos. Den 19de juli gik ildflommen over husene i Dalbær og brændte dem op med næsten hele boen. Den holdt saa frem efter elverenden indtil $1 / 4$ mil ovenfor Kirkjubæjar klaustr. Ildstrommen gik saa ner kirken, at gjenskinnet kom ind gjennem kirkedoren, og klokken gav ekko. Den 20de juli holdt Steingrimsson gudstjeneste i denne kirke, og han og hans tilhorere gil fra kir- 
ken hen for at se, hvorledes ildstrommen var gaaet frem siden messen, og fandt da, at den ikke yar kommet et fodmaal lrengere frem.

Holtsá og Fjarðará lob nu fren over de dæmninger, som det nye hraun havde dannet, og vandet var saa stort, at det var ufarbart med heste dagen efter.

Den sydlige arm af ilden, som holdt sydover efter Skaptís gamle vei, stevnede mod Landbrot ostenfor den saakaldte Vadhella. Der odelagde den gode pladse for marehalm og gik saa i sydost mod Steinmýrarłand. Der havde varet et godt fiskevand, som Skaptá havde odelagt i flomtiden engang $\mathrm{i}$ gamle dage. Bonderne flygtede nu fra sine gaarde, thi de frygtede for, at lavaen skulde flyde helt frem til havet, saa at veien fra Fljotshverfi vestover skulde afspærres.

Den vestlige del af ildstrommen faldt i Landás rende. Den udbredte sig over Eystri og Ytre Ásaland og oversvommede alt med hraun. Ligesaa odelagde den en plads for marehalm, som Ásar eiede. Mdflommen gik udi Kádafjót og standsede overfor Leiðvollr; derved opdæmmedes Túngufljót og Holmsá. Den 12te juli bræudte Nes i Skaptártúnga helt og holdent.

Fra slutningen af juni maaned har her beretningen fulgt Steingrimssons fremstilling. Stephensens er i det hele overensstemmende med denue, som det vil sees af det folgende: Han siger, at fra 22 de juni til $13 \mathrm{de}$ juli kom der af og til nye stromme langs dẹ forlængst opfyldte rende i Skaptá og videre frem over bygden. Det store udbrud af 29 de juni omtaler han ikke specielt. Imellem Skálarstapi og Skaptártínga var, siger han, lavaen ved disse idelige udbrud, ligesom den storknede til, opdynget til en hoi bakke, saa nu kunde den nye lava ikke mere finde saa frit lob som for. Den delte sig derfor $\mathrm{i}$ adskillige arme, hvoraf de to flod frem ved den vestlige og de to andre ved den ostlige side; $\mathrm{en}$ af de vestlige lob især frem over Neshraun og den tilforn oversvommede gaard Botnar, hvoraf intet mere var at se end et lidet faarehus og et stykke af hjemmemarken; den anden derimod, som lob frem efter Landás rende, oversvommede gaarden Nes med huse, enge og det meste af grresmarkerne, samt alle enge, udmarker, skov og sandhavrepladse, horende til prestegaarden Ásar, ligesom og det meste af engene med en del af hjemme- og udmarkerne til gaarden Ytri-Ásar, hvilke begge gaarde ildfloden er gaaet tæet forbi. Præsten fik reddet det meste af sine eiendele $\mathrm{og}$ medtog tillige alle kirkens ornamenter og instrumenter, da han tog flugten til sysselets vestlige cgn.

Fra disse gaarde oversvommede ildstrommen den nedenfor liggende sydlige strækining, og Iob siden mod vesten noget ud $\mathrm{i}$ og ned efter den brede rende af Kúoafljot, en af de allerstorste og mest bekjendte floder i landet, men standsede her tilsidst omtrent i nordnordvest fra gaarden Leiovvollr; nordenfor denne gaar en stor bugt langt ind i lavastrækningen, og det er ikkuu en spidse deraf, der har skudt sig hen i Kádafljot; den ovrige del stryger forbi denne gaards ostligste græsmarker, boies derfra alt mer og mer mod ost, og lober forbi kort nordenfor Staðarholt, og derfra igjen, omtrent efter samme linie, tret nordenfor Hnausar.

Imidlertid stilede den ene af ildflodens ostlige arme sit lob paa Landbrotet langs med Skaptáens rende, som forte herhen, og opbrændte under veis adskillige sandhavrepladse, men standsede dog endelig midt i de saa kaldte Hraunsmelar i Landbrot; den anden arm flod langs hen med Siðafjeldene, oversvømmede den 2den juli, kirken og samtlige huse paa Skál, som for var blevne satte under vand, samt alle gaarden Holt tilhørende enge og de der sondenfor liggende ypperlige marker, opfyldte renden af en tæt ved gaarden lobende elv, kaldet Holtsá, og overdækkede Holt selv, den 6te juli, eller faa dage efter, med evigvarende lava.

Herfra gik ilden videre frem osterefter og lob endnu den 14 de, samt $\mathrm{i}$ de paafolgende tre

frem for 
ikke

net, $\mathrm{og}$

Land-

saa i

flom-

lavaen

Eystri

ehalm,

medes

phen-

er, at

ende i

ecielt.

m den

it lob

de to

svom-

arken;

huse,

rende

ne til

meste

en til

g, $\quad \mathrm{og}$

torste

arden

pidise

ligste

lt, $o g$

med

tand-

med

levne

erlige

Holt

dage indtil den 17 de juli, langs med Slaptáens rende, over elven Fjadará, hvilken den gauske tilstoppede; dog flod den storste mangde frem over det hoie randfald i Skaptŕen, Stapafoss kaldet, og opfyldte endelig det uhyre svelg, som dette store vandfald havde i mange fremfarne aarhundrede gravet eller udhulet neden for sig. Lavaen oversvommede her endnu Dalbær i Landbrot med alle dens huse samt en stor del af hjemme- og udmarkerne, efter at den meget havde beskadiget gaarderne Heiði og Hankurbakki paa Siða; desuagtet kan endnu hver af dem fode en familie. Gaarden Holmur i Landbrot blev og herved noget beskadiget, da den paa den nordlige side blev trængt af lavastrommen, og paa den sydlige af det ved ildfloden opdæmmede vand. Lundelig standsede denne ostlige arm eller spidse af ildstrommen den 20de juli strax vestenfor den særskilte klippe, Systrastapi kaldet, der ligger i det hoieste $1 / 4$ mil vestenfor Kirkebrejar klaustur.

Allerede i september 1783 gik man, efter Steingrimsson, med al færsel over hraunet i Skaptírdalr. Han bemærker derhos, at til den 14 de januar 1784 saa man to sluer fra denue vestre gjá, det vil sige fra den sydvestlige kraterrække.

Ovenfor er omtalt den lavastrom, som kom frem efter Skaptás rende, udfyldte denne og saa strømmede ud over det foranliggende land. Men en lignende odelrgggende ildstrom skulde snart komme frem efter Hverfisflóts rende.

Efter Stephensen begyndte udbrudet her den 28de juni (skal sikkerlig være juli), da en tyk og sort banke af sandskyer og rog fra ildsprudningsstedet trak sig over for en stærk nordnordvestlig vind og foraarsagede først næsten over den hele bygd Fljótshverfi og den ostlige del af den egentlige Sið $a$ et saa forfærdeligt mørke, at man om middagen knapt kunde skjelne et hvidt ark papir, som man $\mathrm{i}$ husene holdt op mod vinduet, fra den morke ræg. Allerede den 14 de juli var og ved hoilys dag over Siða trukket op et ligesaa usædvanligt, skjønt ikke saa forfærdeligt mørke som dette; thi nu regnede over hele Fljótshrverfi, de to ostligste gaarde Nípstaðr og Raudaberg alene undtagne, store, glodende stenskiver med en uhyre mængde sand og aske, som ganske bortsved alt græsset af markerne, forgiftede jord og vand for mennesker og dyr, ja nær havde stukket ild paa husene selv, hvor disse blev overdækkede af den nedfaldende aske og stene.

Steingrimsson beretter, at den 29de juli hortes forst tegn til udbrud i nordost for Kaldbakur. Larm og dundren var ikke mindre end i det vestlige udbrudssted, som nu for det meste var roligt. Der kom op en frygtelig skybanke, og sand faldt over Fljotshverfi og den østlige del af Siða. Knald og tordenslag hørtes uafbrudt, saa der indtraf neppe nogen stands. Den 30te fortes ilden frem efter Hverfisfljots glafur, som var næsten ligesaa dybt som Skaptírglafur, og vandet var lidt mindre end Skaptá. Den dag reiste Steingrimsson over dette store vasdrag, og det var da neppe farbart for varme. Den 1ste, 2 den og 3 die august holdt dette ved paa samme vis. Ilden torrede elven op, og heraf benyttede beboerne sig, idet de drog ud til elveosen, som da var bleven saa grund, at folk kunde vade, og her fangedes 26 sel. Den 7 de august kom ilden frem af Hverfistljotsgláfur. Den 8de og 9de august holdt den frem efter renden. Ildflommen holdt paa at lægge den ene lavastrom op paa den anden indtil den 14de august; da standsede den, efter at have odelagt to gaarde, som hed Ytri- og Eystri-Dalbar.

Fra 10de til 17de august var det godt veir, men i den østlige gja eller spalte holdt samme udbrud ved. Da folk troede, at ilden kunde fare over Fljotshverfi, forsogte Steingrimsson den 20 de august at reise didhen til Kálfafells kirke, og det lykkedes ham at komme over Brunná.

Den 1ste september kom der en anden ildflom paany fra det ostre udbrudssted. Den gik frem foran Seljaland og odelagde alle de slaattemarker nedenfor bakkerne, som Seljaland eiede 
Brunni diemmedes op ner Sitpar. Ildstrommen gilk saa efter elven frem mod Hooll og standsede der, saa farerselsveien ikke odelagdes. Brumní fik udlob langs det gamle hraun, men beskadigede slaattemaxken pa Núpar. Hele den uge gik der frygtelige tordenveir og lyn. Den 10de og 11te september kom der ny ildflod ud af gjíen og gik indenfor det hram, som for var kommet. Den 13de kom der aske, men fia den 1tde til den 20de september rar det tauleligt roligt. Den 26de septembex kom der strerke jordskjælv, og udbrudet holdt ved til 24de oktober. 25̃de olktober slog der op en ildslue, som gik hoit op i luften og varede i ja dage. Denne ildflom fyldte ud hele glufret og alt lavland mellem Miklafell og Eiriksfell, gik vestenfor der, hvor Ytridalr havde staaet og fyldte hele dalen. Ligeledes lob den langt ud over det gamle hram og forhoiede det mere end halvparten og lob ud over Seljaliandsoren, som var en udmærket slatteplads. Det udbrud var det sidste, men efter Steingrimsson tillige det voldsomste og gik frem med firygtelig fart.

Hele november holdt ilden para at stromme fra det ostlige udbrudssted og til det astlige hraun.

Stephensens beskrivelse afviger noget fra Steingrimsson, forsaavidt som denne lader lavastrommen komme ud af Hverfisfljots rende den 7 de august, Stephensen den 9de august. Udbrudene den Iste september, 10de september og 25 de oktober.omtaler Stephensen ikke. Han beskriver udfyldningen af Hverfisfljots rende salaledes:

Den 3die amgust blev man allerforst var en af floden Hvertisfljót opstigende rog og erfarede derhos, at den strerke hede, som da allerede var opkommen i deme flod (der ikke gav Skaptáen meget efter i storrelse, men var tillige sala meget farligere for reisende, som den brod frem med en paa sine steder endnu mer strid og rivende strom, samt havde en langt usikrere grund en Skaptáen), tog daglig mer og mer til, indtil floden selv, far dage efter, ganske forsvandt og udtorredes. Dette kunde ei andet end opvekke den allerstorste fiygt og rengstelse hos beboerne $\mathrm{i}$ det hele herred, som, allerede forskrækkede over hine sorgelige odelrggelser iblandt sine naboer, par lige made forkyndte $\mathrm{i}$ forveion red Skaptáens udtorrelse, gruedes ved dette forstyrrelsens budskab. Udfaldet viste $o g$, at deres frygt var grundet, og at denne salsomme tildragelse i naturen ogsaa her skulde bebude en anden og storre. Man saa nemlig, om morgenen den 9de august, forferdelige rogstotter at opstige langt borte fra fjeldene mod norden; de synes immer at nerme sig, og tilsidst at udgjore ligesom en v'eg eller banke oven paa jorden. Idelig lynen med starke skxalde og dundre opstod af denne strækining, og endelig brod en brusende ildstrom frem efter renden af HverfisHjot, med saadan en fart, som om floden sely nu kunde brekket los igjen. Denne ildstrom bredede sig vidt ud over den kort sondenfor liggende vidloftige sandstrækning, hror den allene en eneste aften, den Gde august, flod frem over en mils vei imod sonden fra den saakaldte Orrustuholl (det er en bakke, hror der blev holdt trekamp i gamle dage), og derved tilsperrede den alfare vei mellem Fḷjótshyerfi og sida.

Tdelige nye udflod fira fjeldene udvidede denne lavastrekning i bygden tid efter anden, og oversvommede endelig, sidst i august matued, gatardene Eystradalr og pverírdalr, som med huse og hjemmemarker, samt det meste af enge og grresmarker, ere blevne skjulte af lava, og stedet, hvor de for lat, er ikke mer synligt. Disse senere ulflod have og meget beskadiget gaardene Seljaland og og pverí og forjaget disses beboere, som og alle mennesker i denne bygd, eller Kálfafells kirkesogn, omendskjont ingen huse der er af brendte, uden paa de 2 forstnevnte gaarde, Eystradal ogr pvérardal.

Ligesom den ostlige ildstrom er frembrult lenge efter den vestlige, saa haver og ilden na-

turlig

forsili som,

til de

sendt

eller

1881

1784

kerne

ypper

ikke

man

Dog

nede

fjelde

Mikla

var $\mathrm{r}$

folgen

bedro

lutter

vider

dette

som $f$

længst

storre

stedet

udspr

kartet

forsog

30 til

hed,

at de

forsog

stykk

bagey

rog $n$

overs

fyldt

kom

han 
turligvis brendt og ulmet endog $\mathrm{i}$ aaret 1784, strerkere og langere $\mathrm{i}$ hin, end $\mathrm{i}$ denne; ja man har forsikxet: at her endnu i februar mamed afvigte an 1784, er fornummet et nyt udflod fra fjeldene, som, tilligemed de foregaaende, vel ogsaa haver gjort sit til at opdynge lavaen $\mathrm{i}$ den ostlige arm, til dens nuverende, paa mange steder meget betydelige hoides.

- Der er, saavidt jeg red, kum foretaget tre reiser for at soge efter de livatere, der har udsendt disse lavamasser. Forst reiste Magnus Stephensen, som tidligere omtalt i denne egn i 1784 eller aaret efter udbrudet; saa kom Svemn Pálsson i 1794 til de sydvestlige kratere, men forst i 1881 blev kraterrækken opgaaet $\mathrm{i}$ dens hele læengde af cand. real. Andr. M. Hansen og mig.

Stephensen, hvis telt stod mellem Prestbakki og Mortúnga paa Sida, reiste den 16de juli 1784 tilfjelds, og beretter, at han, strax han kom og paa heierne, faldt i forundring over gresmarkernes bedrovelige udseende. Der hror enkelte gaarde paa Sida havde havt sine spetere for de ypperlige beiters skyld, saa man nu alene en af glodende sand og aske forsveden jord, hror den ikke rar skjult under et kulsort drekke af en uhyre mangde vulkansk aske og grus. Jo laenger man kom op tilfjelds, desto hoiere laa asken paa markerne og allevegne fia 4 til 6 tommer hoi. Dog var den allerde sunket fra forrige aar, og paa enkelte steder begyndte nogle fat, dog halvvisnede urter og straa at lade sig tilsyne.

Den rei, Stephensen har reist, lader sig ikke godt folge i detaillen, da de af ham nevnte fjelde tildels er urigtig aflagte paa hams kart. Han har imidlertid raret ved den ostlige lavastrom ved Miklafell. Der opsteg da mangfoldige rogstotter paa de fleste steder af lavastrommen, men isar var rogen gamske forfrerdelig et sted midt i Hrerfisflóts rende. Ved Miklafell gik han med sine folgensend ud paa selve lavaen, savidt han kunde taale at gaa for hede. Fra dette fjeld var udsigten bedrovelig: mod nord og ost saaes den nye sorte lava tret ved det store gyselige isbjerg og iovrigt lutter sorte strekninger, bedrkket af den uhyre mangde sand og aske. Han fulgte lavastrekningen videre mod nord og kom ved solens nedgang til Blangur. Med stort besvar kravlede han op paa dette fjeld. Den rog, som steg op af lavastrakningen nordenfor Blængur, var ligesaa ubeskrivelig som forfardelig $o g$ hindrede ogsaa meget udsigten fra dette ellers sardeles bekvemme sted. Allerlangst borte, hvor han kunde se lavaen, kom der tilsyne en stor hoi ligesom et lidet bjerg og af storre onfang end hoide, hvoraf der opsteg en meget tyk, sortblandet rog. Han sluttede, at udbrudsstedet matte vere her, og mente, at hele den forfierdelige lavamasse er udflydt fia et og samme udspring og rimeligst fra det ontalte bjerg. Efter det punkt, hvor han afsetter sin vulkan paa kartet, ligger det næmmest at antage, at det bjerg, han har seet, er fjeldet Laki (se kartet). Han forsogte at fortsnette reisen derhen, men erfarede, hvor vanskeligt det var; thi da han var liommet 30 til 40 farne ind paa lavastrekningen, blev den mere og mere farlig og usikker og saa brandende hed, at man umulig kunde staa der. Den tykke opstigende rog onhyllede dem fra alle sider, saa at de snart ikke mere vidste, til hvilken side de skulde vende sig for at slippe ud igjen. Et nyt forsog par et andet sted ost for Blangur lob ligeledes uheldigt af. Han fulgte lavaen et langt stykke mod syd og sydrest og giorde atter et forgjeves forsog paa at naa over hraunet. Paa tilbageveien fulgte han lavaen til Hellisá og beretter, at en strerk rog stod op af Skaptárgljufr, hvilken rog man i meget lang afstand kunde skjeldne fra den orrige rog, og folgelig kunde man tydelig overse beliggenheden af Skaptís hele rende nordenfor og alle dens bugter, forsaavidt den var opfyld af lava. Ved Hellisá boiede han af og tog korteste vei ostover forbi Geirlandshraun og ankom kl. 1 om natten for den 18 de juli tilbage til sit telt mellem Prestbakki og Mortúmá. Da han reiste ud $k l .4$ om morgenen den 16 de juli, havde han altsaa veret henved 2 dogn paa reisen. 
Sveinn Pálsson drog den 30te juli 1794 fra gaarden Geirland langs den vestre side af Geirlandsá til odegaarden Helgustaor, vestenfor hvilken elven Stjorn rinder gjennem dalen. Fjeldene heromkring var nu græsrige. Han fortsatte reisen mod nord, ost for det saakaldte Geirlandshraun, et fjeld, og ikke, som navnet skulde antyde, en lavastrækningr. Ost for Geirlandshraun damner Geirlandsá en vakker fos, som kaldes Fagrifoss. Veien falder tæt forbi samme til en bjergaas Lanffell. Omkring og især vest for Lauffell er godt beite og egnen flad med smaa og store myrer, hvor en mængde svaner opholder sig i den tid, de begynder at frelde fjær. Egnen kaldes Lauffells Mýrar og er saaledes beskaffen helt til Hellisá, en elv, som har sit navn efter en hule, (hellir) som nu er nedfalden. Han kom let over Hellisá, skjont den læengere ned, er opdæmmet af lava. Veien gik videre vest for Olduskér, hvor der for 1783 skal have været næsten uoverkommelige moradser, men som nu var opfyldt af pimpsten. Efter at være overfaldet af stærk skylregn fortsatte de reisen mod nord langs den vestlige lavastrom til Blágil, hvor de satte sit telt paa den nogue sand tæet sydvest for et fjeld Galti, om eftermiddagen kl. 4. De kunde sidde i teltet uden at oversvømmes af regnvandet, da sanden opsugede dette, men de var i hoi grad plagede af myg, der efter Pálsson især holder til i og omkring nylig flydte lavaer. Om aftenen kl. 10 holdt regnen op, og vinden dreiede sig til nordnordvest. De gik da op paa Galti for at se beliggenheden af den vestlige lavastrom og for at udse et sted, hvor lavastrommen var smalest og lettest at gaa over for at komme til selve udbrudsstedet. De bemærkede her et sted, nordvest for Galti, hvor overgangen over hraunet syntes at falde beleiligst til nogle paa den anden side af lavastrommen staaende rodagtige, af toppen ryggende koniske hoie.

Den folgende dag den 31te juli var vinden fra sydvest med taage og stærke regnbyger, og de maatte ligge i teltet til over middag; da det begyndte at lette kil. 3, gik Pálsson, selv tredie, tilfods henimod det sted, han havde udseet sig nordvest for Galti. Her var hraunet omkring $1 / 2$ mil bredt. Der var ranskeligheder ved overgangen, idet hele lavahvalvninger faldt ned under dem. Midt i hraunet horte de stærk susen af vand mod sydvest, som de troede kom fri: en gja eller sprække, men de fortsatte sin rei uden at blive noget var. Hraunet bestod paa dette sted mestendels af flade horizontale klipper, hrorover veien var let, men derimellem laa store og smaa dynger og klumper af los, sammenkastet, tildels forfærdelig hul og sprækkefuld lava, og her matte de paa hrender og fodder kravle sig igjennem, mange gange erfarende, at den hump, de sidst trak sin fod fra, faldt i det samme ned og blev til en frel mork hule.

Pálsson fortsætter her beskrivelsen af kraterne saaledes:

»Endelig kom vi til en dyb, men i bunden ganske lige og flak, temmelig bred Kloft eller Dal, hvori Ildfloden tydelig kunde sees at have taget sit sidste og fornemste Lob og storknet med et viden Revner. Vi kom lykkelig her over og tillige den heele vestlige Lavaarm og befundt os nu ved Rodderue af de omtalte rygende Hoie, glade over at være de forste, der kom over Lava Strækningen paa dette foronskede Strd.

Efter et Øiebliks Pusten besteeg vi den nærmeste og efter Anseelse største Høi. Jo hoiere jeg kom op ad samme, jo losere og aabnere blev Grunden og til sidst ved Toppen saa hul, at jeg maatte anvende al min Varsomhed for ikke at falde ned i Afgrunden, men hvor blev jeg ikke bestyrtet, da jeg naaede Toppen og saae, at Hoien indvendig var ganske indhulet, omtrent som man kan forestille sig en Islandsk Faare-Borg uden Top eller et noget nær elliptisk Giærde. Gulvet var af lige Hoide med Hoiens udvendige Rod, ganske lige og bestaaende af solid Lava, men Væggene onkring indentil af lagvis ligesom opstablede, hist og her yderlig forbrendte Hraunstykker, 
eller

d et

ved

rek-

siere

og de overste tynde Bredder af samme fulde af utallige parallele smaa Sprekker, som lob cirkulær eller concentrisk med selve Begeret. Op af disse Rifter steeg den frele og hæslig lugtende Rog, og man kunde hore en styg Susen dybt nedi samme. Paa den ene Side af dette Lavagiærde var en Udgang eller Dor lige hoi med Gulvet og af samme Beskaffenhed samt en smal Rende der fra ned til Hovedlavaen eller den ommeldte store Rende. Denne Hoi havde tvende slige Udhulninger eller Begere, hvor af den ene havde banet sig Udgang mod S.V., den anden mod N.O., og Begerets Diameter oventil kan ansættes til 30 og i Bunden 10 Favne.

Inden til ned ad Væeggene hrengte mangfoldige mest rod og gron glasserede Lavastalaetiter, men da man nærmede sig samme for at brække nogle ud, var hele Stykker af Værgen istand til at styrte ind og slaa en Hovedet i toe.

At dette var ordentlige Volean Kratere, siger sig selv og behover intet videre Bevis. Jeg betragtede nogle flere af disse Hoie, men fandt dem alle af eens Beskaffenhed. Udvendig bestalae de alle af rode, ganske forbrændte Skursteensstykker og Grus, men indvendig og $\mathrm{i}$ Bunden af solidere Lava, og fra hver gaaer en Udgang eller speeiel Rende til Hovedrenden. Alle vegne ved deres Rodder findes udbrendte eller kolde Svovelminer, kuns et Par forekom med levende Svovel. Overst i Dagen laae her nogle hvidagtige eller forvittrede Gibsdele, derunder kom det levende Svovel af det losere Slags (Isl. Fylusteinn), som i Dybden blev alt meer og meer rodagtig gult. Under denne laae et stratum af adskilte, rode Lava Stykker, hvori tillige endeel Svovel fandtes anskudt. Noget nordosten for forstomtalte Hoi bleve vi i Kanten af Lavafloden en strerk Rogstotte vaer og famdt, at samme kom op af en Sprrekke fuld med halvlunket Vand, der stinkede ubeskrivelig, men var dog uden synderlig slem Smag, og afsatte en Mrengde af den saakaldte Cromor Thermamu, fra hvilken uden Tvivl det meste af Stanken opkom. Ingen Slags saltagtige Ansættelser kunde jeg opdage, hverken i selve Lavaen ikke heller omkring i Begerne. Rimeligt alt saadant er ved foregaaende Regn opløst og bortskyllet.

Af slige storre og mindre Volean Hoie kan der paa dette Strog trelles henimod en Snees, der ligge tæt ved hinanden, i en Ræklie fra ONO til VSV, der udgior henved 2 Mil; have ventelig aabnet Scenen 1783, brendt alle paa engang lig en heel Rad store Smelte Ovne, hver med sin egen Rende udgydet den smeltede Lava-Naterie til Hovedrenden eller den tat forbi Hoiene strygende vestlige Lavaarm, der siden har befordret samme videre frem.

Paa den hele nordvestlige Side af denne Volean Række ligger en Klynge græslose, af lutter smaat Grus bestaaende rundagtige eller halvkugledannede Fieldhumper. Disse er blevne aldeles urorte af Voleanen og ere en god Deel hoiere end de ommreldte ndhoie selv. Deres Udseende viser dog, at de i celdgamle Tider ere damnede ved Jordbrand, skiondt de fleste ikke vil erindre at have seet noget Lava omkring samme for 1783. Norden omkring disse Field har den bekiendte Skaptá sit forrige uhindrede Lob lige til Gabet af Úlfarsdalr. Men ovemmeldte, af Inden urorte Fieldklynge er de for saakaldte Úlfarsdalsskér.

Formedelst Nattens Nærmelse kunde vi intet videre udrette, men matte see at komme tilbage. Efter at vi da havde stablet en temmelig stor Varde eller Dynge af Hraunsteen op kort nordasten for den forst besogte, storste og dobbelte Kamin, der ligger omtrent i Midten af de ovrige Hoie og paa sammes overste Steen lagt en Dansk Kobbermynt til Bevis paa, vi vare paa Stædet, vendte vi om og kom i netop 1 Time over. Hraunet paa et Stred, hvor let kunde anlægges en med Heste og Alting passabel Vei. Thi i Almindelighed kan paastaaes, jo nærmere Opsprudningens Strederne jo fastere, slettere og jevnere er Lavaen, hvortil Aarsagen er let at begribe, nam man 


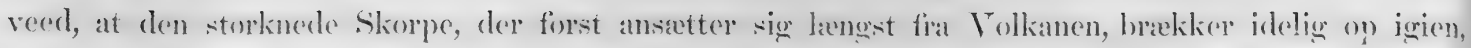

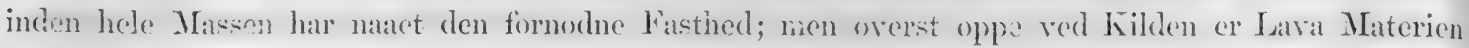
stedse i Flod, saalienge Eruptionen varer, men storkner, siden med et, ikke at tale om, at den storste Deel af Lava Massen maa vare nedgleden til de laveste Streder eller Boigder og folgelig her vare

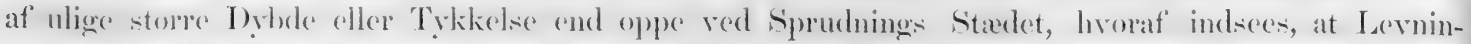
gerne af den Volean, man ved at have raset etsteds i Nierheden af' denne sidste, for'st i det 12 te Aarhundrede, kan gierne i sala lang Tid til 1783 ræe forswundne eller blevne lidet merkelige for Mrngden oppe ved Kilderne selv, skiondt de lenge vil kunde betragtes nede i Boigden. Vi kom til vort 'T'it on Natten KI. 11 med ganske sonderslidte Vanter og Skoe, hror af enhver af os dog var forsynet med tvende paa Landets Maneer forferdigede af raat Oxe Læeder. For at hæve de i slige Tilfrelde i Fodderne opkommende Smerter, overstrog vi samme med roget Lammefit, ikke uden markelig Fordeel.

Den 1ste august drog Pálsson mod nordost ostenfor Galti henimod Bliengur og foretog sine peilinger fra en top strax sydrest for Blængur og kun lidet lavere end dettefjeld. Han havde da de hoie eller liratere, som han den foregaaende dag havde undersogt, i vest til nord, liggende række paa den anden side af lavastrommen. Ost for Laki og nord for Blængur siges egnen for 1783 at have været flad, skjont uden græs lige til det sted, hvor Skaptá har sit udspring af Skaptárjokull, hvis rand lober her ganske flad og grusbedækket fra nordnordvest mod sydsydost. Han omtaler, at der strax ostenfor Laki begynder en rad sammeslags rodagtige hoie som vestenfor. Tallet paa disse hoie kan han ikke noie bestemme, da mangfoldige af dem er ganske ubetydelige, rentelig nresten begravne i den opveldende lava, der saa at sige ikke har vidst, hvor den skulde hen paa denne slette, til den endelig or opdynget til en fornoden hoide for at naa udlob til Hverfisfljot mod sydost. Sveinn Pálssen reiste samme, dag, 1ste august, tilbage til Blágil og derfra kl..31/2 samme eftermiddag og kom tilbage til Geirland $\mathrm{kl}$. $11 \frac{1}{4}$ om natten og brugte altsaa 3 dage til excursionen.

Vor Islandsreise begyndte i Seydisfjordr paa ostkysten, hvorfra vi red til vulkanerne omkring Mývatn. Herfar var det hensigten at reise tvert igjennem Island sydover Sprengisandr og derfra videre sydover mellem Fiskevotn til vulkanen af 1783. Det er mig ikke bekjendt, at nogen har forsogt at reise denne vei, men da streger paa Gumnlaugssons kart antydede, at der var fremkommeligt, besluttede vi at forsoge denne vei gjennem odemarkene. Vi reiste fra garden Mýri i Bárdardalr den 21de juli, og kom on aftenen til Kiðagil, teltplads paa det sidste sted, hror der findes græs for farten over den orkenagtige Sprengisandr. Den folgende dag, den 22de juli, kom vi efter 15 timers ridt over Sprengisandr, men fandt ikke det sted, hvor hestene lian beite, og som kaldes Eivindarkofaver, hvorfor vi maatte overnatte paa et myrlændt sted, hvor det kun fandtes lidet grres. Den folgende dag drog vi sydover mod Fiskivotn. Her traf vi istedetfor den indso, der paa (xumnlaugssons kart kaldes porisvatn, og som her er afsat med en lrengde paa $3 / 8$ geografisk mil, en meget betydelig indso, sikkert flere mile lang, og visseligen en af Islands storste vandansamlinger. $\mathrm{Vi}$ var den dag, den $23 d e$ juli, nodt til at ride fra kl. 9 om morgenen, hele dagen og natten til den folgende dags morgen kl. 5, da vi kom til en dal, sandsynligvis ved póristungur, hror vi fandt græs og bler til den folgende dag, uden at vide, hvor vi befandt os. Den 24 de juli slap vi med nod og neppe over 'Tungná, drog op mod et fjeld, der siden viste sig at vere Hekla, red ligeforbi Heklas lavastrom af 1878, og kom omsider ned til en gaard, som heder Galtalcekr, ikke langt fra Hekla. Vi tilbagelagde saledes, ukjendte som vi var, heldigen hine 25 til 30 geografiske mile

r.jenn beslut og $k 0$ dalle med med. Geirla fulote

flere pregti optraes og pas telt vo gyndte ninger som $\mathrm{k}$ imod gjorde steder lem. Eftera sig at drede, op pai son d pen af nordye bage 0

neppe lettede at van stor 1 overste demne del sor hulen bedre langs 1 sydvest 
gjennem Islands odemarker, men vi var komne 10 til 12 mile. langer vestligt, end vi tilsigtede, Vi besluttede da, efter en reise til Geysir og Reykjarik, at drage tilbage langs sydleysten af Island og kom til Skaptafellssyssel henimod midten af august matued.

Vor reise til kraterne begyndte sondagen den 14de august 1881 kl. 12 fra gaarden Horgsdalr paa Sixa. Bonden Bjarne paa Horgsdalr forsynede os med friske heste, ligesom han sely fulgte med paa reisen, saa at vi ialt var fire, idet vor folgemand fra Seydisfjordr Gisle Postur ogsaa blev med. Vi red fra Horgsdall trers over den dal, som gaar ind forbi Prestbakki, tor op den saakaldte Geirlandsklev, og kom efter et par timers ridt til guarden Eint́maháls, 221 meter o. h. Senere fulgte vi i det hele den af Sreimn Pálsson beskrevne vei.

Fra Eintúmaháls red ri et kort stykke langs elven Stjórn. Vakre basaltsoiler forekommer flere steder paa denne strekning. Vi red over to arme af Geirlandsá, af hvilke den ene danner en pregtig fos, kaldet Fagrifoss, der styrter sig ned i et dybt erosionsleie, hvor basaltanange med soiler optrader, dels i selve fossen dels i en ryg i leiets bund, og efterat vi havde redet langs Lauffell og passeret Hellisá, kom vi efter 6 timers ridt henimod $\mathrm{kl} .6 \mathrm{om}$ aftenen ned til lavastrommen og slog telt ved Blágil paa det sted, der par kartet or betegnet som liggende 446 meter over havet; her begyndte vi at speide efter katerne. Lavastiommen laa takket og nogen, dog med grai mos i forsenkningerne, og paa den anden eller nordvestlige side af strommen, sala vi nogle forhoininger i terrainet, som kunde vare kraterne, og henimod disse begyndte vi at vandre on aftenen. Lavaen bestod ud imod kanterne mest af blok i blok, men det mosdakke, der mu havde lagt sig over hist og her, gjorde vandringen mindre besvarlig, end den efter beskrivelsen var for vore forgjengere. Patandre steder var strommen jacvnere, bestaaende mest af brudte flag med talrige sprekker eller giáer imellem. Strommen har paa sine steder omkrandset hoie dele af landet, som nu ligger som oer i lavaen. Efterat vi havde vandret $i \frac{1}{2} 2$ time, kom vi til de formodede kratere, der ogsal cranske rigtig viste sig at være saadanne; men de bar kjendetegn af at vere gamle. De var mange $\mathrm{i}$ antal, flere hundrede, saaledes at landet bestod af krater i krater, og fia nogle af dem var der fyldt lava. Vi grik op paa toppen af det overste, som findtes at ligge 510 meter over havet. Disse gamle kiratere er, som det vil sees, paa kartet angivet med mork furve og ligger nordvestligt for Olduskér. Fra toppen af disse kratere saa vi imidlertid tydeligt et par af de storre kratere, som vi sogrte efter, i nordvestlig retning. Men da det var sent om aftenen og morket snart faldt paa, vandrede vi tilbage over strommen igjen til teltet og gik tilro $i$ haab om den neste dag at naa kraterne af 1783.

Tidlig den folgende morgen befandtes det hele landskab indhyllet i tret taage, saa vi neppe kunde se 10 skridt fra os, og der var ikke andet raad end at vente, indtil taagen lettede. Da vi havde ligget den halve dag i det lille soldatertelt, besluttede vi trods talagen at vandre ud paa lavastrommen. Da ri havde gaaet fremad et stykke $\mathrm{i}$ tangen, traf yi paa en stor hule, som var 50 skridt lang og 10 skridt bred, og som sandsynligvis rar dannet, medens den overste del af lavastrommen var storknet, og medens en del af den ovrige lava endnu var flydende; denne endnu flydende del har fundet anledning til at stromme videre, efterladende den storknede del som et tag over en hule. Af disse huler er der ikke saa far i lavastrommene. Vi fandt hulen at ligge 458 meter over havet og lavaens hoieste punkt i dette tversnit 492 meter.

Taagen vedblev imidlertid at ligge lige ihærdigt, og vi vandrede tilbage til teltet $\mathrm{i}$ haab om bedre lykke den neste dag. Efter en kjolig nat blev det on morgenen taalelig klart, og vi red da langs lavastrommen mellem denme og fjeldet Galti, indtil vi kom i sydost foran det storte af de sydvestligste kratere i Lakis rakke og satte saa tilfods tvert over lavastrommen, indtil vi naaede 
det nævinte krater. Her begyndte en meget interessant vaudring fra krater til krater hele dagen igjennem, indtil vi naaede fjeldet Laki.

Selve kraterne bestaar. ikke af andet end af lose slakkemasser; de har meget forskjellig starrelse og gives af alle dimensioner fra kun 4 til 5 meter i diameter ved toppen indtil 150 meter og maaske lidt større. Ligesaa variabel som bredden er hoiden, thi denne varierer fra et par meter hos de smaa op til henimod 100 meter hos de store. Det enkelte krater har, naar det ligger isoleret og sees fra siden, formen af en ret afstumpet kegle, men gaar man op paa det overste af deme, saa viser den sig indvendig hul, skaalformet, saa at hele kraterer har formen af en kredsformig opkastet vold. I det indre af denne hoie vold ligger det sted, hvor lavaen er kommet op, og ikke sjelden sees lava i selve bunden, men ofte er slakkernenfra kraterets sider faldne ned i kraterets bund, saa at der er slakker ogsaa i bunden. Forat skaffe lavastrommene udlob er vaggene giennembrudte paa 1, 2, 3, ja undertiden paa flere steder, men der gives ogsaa kratere, hvor væggene slet ikke er gjennembrudte, og hvor slakkerue altsaa danner en hel cirkelformet vold.

Gjennemsnitet af kraterne er oftest ilke fuldkomment cirkulært, men aflangt, elliptisk, efter den vulkanske linies retning, som her er sydvestlig. Undertiden ligger det ene krater saa nær ind paa det andet, at de begge har fælles sider, saaledes at det ene svrelg kun er adskilt fra det andet ved en smal skrobelig slakkerand, og hvor flere saadanne svælg ligger efter hverendre, der bortfalder delvis den typiske kraterform, sal der opstaar en kraterryg af slakker mod den ene fordybning efter den anden.

Paa en 20 kilometer lang linie kan man nu folge slige kratere det ene efter det andet, sommesteds helt kontinuerligt, sommesteder afbrudt; men de steder, hvor kraterrækken er afbrudt, er aldrig meget lange. Paa vor vandring fra krater til krater anstillede vi omtrent halvhundrede maalinger af forskjellige punkter med to barometre.

Tænker man sig nu disse kratere eller; som Islændingerne betegnende kalder dem »borge«, liggende den ene efter den anden paa en lang række, og at hvert af de hundrede kratere udsender en, to eller flere stromme snart til en side, snart til en anden, og at disse stromme gaar i hverandre, saa at de helt omsvommer kraterue og danner milevide lavamarker, der som mægtig stivnede floder flyder ned til bygden, saa er dette et billede af denne mrrkelige egn.

Da Sveinn Pálsson var her i 1794, altsaa 11 aar efter udbruddet, var der som for omtalt endnu tydelige: spor af den vulkanske virksomhed. Kraterhøiene udsendte endnu rog og langs foden af kraterne var der af'sat svovl. Disse spor af vulkansk virksomhed var nu helt forsvundne.

Vi gjennemvandrede rækken af kratere i lobet af 2 dage fra sydvest til nordost, idet vi maalte hoiderne. Barometerstanden var temmelig jevn disse to dage, og barometrene stemte noksaa godt, saa at der er grund til at tro, at hoidemaalingerne er taalelig nøiagtige.

Paa de tre islandske meteorologiske stationer var nemlig barometerstanden den 16de og 17 de august 1881 :

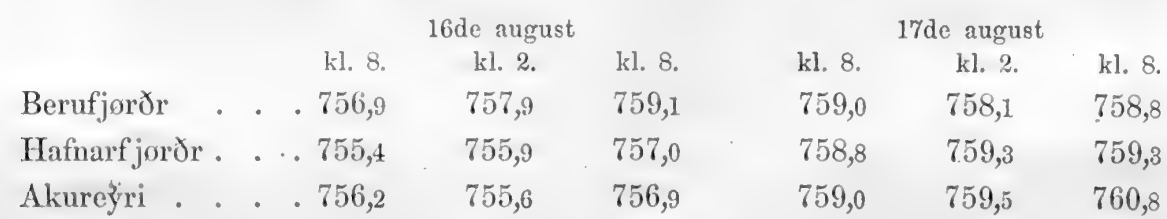

Rokken begynder sydvestligst med et par smaa kratere, indtil der fra det krater, der er 
betegnet som' no. 1, ligger en kontinuerlig rad af deslige koniske slakkehobe: Selvo kraterne bestaar som berort sf slakker, og imellem dem og red deres fod ligger ogsaa sædvanligvis slakker, saaledes som paa kartet ved farrer antydet. En speciel beskrivelse af hvert enkelt kiater vilde fore til gjentagelser; de kan variere med hensyn til hoide, bredde, fremdeles eftersom de har ingen, en, to eller tre udlobsaabninger til siden for lavaen, deres bund kan rar helt drkket af slakker, eller den faste lava kan staa i bunden, og undertiden kin samme sakkehang have flere beegere, sala at der fremkommer dobbelte eller mangedobbelte kratere, men idet hele er de alle bygrgede efter samme prineip.

Igjennem slakkerne og igjennem den paa mangfoldig ris sprukne lava siver vandet let bort, og mangelen paa vand var derfor ret folelig under vandringen $\mathrm{i}$ disse torre storede slakkehobe. Det var derfor gledeligt at finde, at der $\mathrm{i}$ et af kraterne (no. 7) var en liden so med lioldt godt vand. Igjennem de orrige kraterskaale havde vandet allevegne fundet vei nedad.

Af $\mathrm{og}$ til kom der taage hele dagen og nodte os til nu $\mathrm{og}$ da at indstille vore maalinger; men det rarede $\mathrm{i}$ regelen iklie længe.

Om eftermiddagen nermede vi os det af palagonittuf bestalende fjeld Laki og fik her anledning til at undersoge, hrorledes den vulkanske spalte, langs hvilken disse kratere ligger, forholder sig, idet den stoder paa dette fjeld. Det viste sig da, at dette fjeld ikke var helt brustet, men et par smaa kratere angar, hvorledes spalten stoppede op ind inod fjeldet i ringe afstand fra fjeldets fod.

Vi vandrede videre op over ryggen par fjeldet og fandt da, at der paa den nordostre side laa lignende kratere. De strekker sig nedover ryggen paa den nordostre side, antydende det sted, hror sildlinienz eller spalten begynder paa den anden side af ryggen.

Taage skjulte desverre udsigten fra Laki; fra toppen af dette fjeld maia man i lilart veir have den mærkeligste udsigt over kraterrekken til begge sider og til jokellen mod nordost og til lavastrommene rundt omkring.

Om aftenen og om natten havde vi efter dagens besverligheder en temmelig lang vandring at foretage for at gjenfinde vor forer med telt $o g$ heste. Disse var nemlig reist temmelig lang rei bort, da der ikke var gres i nærheden, men hestesporene forte os omsider om natten tilbage til teltet.

Den folgende morgen fortsatte vi vor vandring til kraterræklken mod nordost og tillige 'til de nordligt for disse liggende gamle kratere, der paa kartet er angivet med hoidene 625 meter og 676 meter, samt til det fjeld, nordostligt for Laki, som har hoiden 700 meter; ogsaa dette fjeld bestaar af palagonittuf med stotter af basalt; saakaldte »vindmærker«, mærker, som de af vinden drevne sandkorn i tidernes lob satter paa overfladen, var hyppige. Nordlig for dette fjeld saa vi den paa kartet afsatte indso, af hvilken vi antager, Skaptá lober ud.

De gamle kratere, der stikker op af' lavamarkerne i denne egn, vidner tydelig nok om eruptioner i gammel tid. De ligger imidlertid ikke efter en saa udpreget linie som de nye kratere, men samler sig i grupper. Den nordligste gruppe, ved hvilken hoiden 625 er angivet, bestod af omkring 100 bitte smaa kratere, der havde udsendt lavastromme mod nordnordost, nordost og sydost. De er af meget ringe hoide. Lavastrommen ved deres fod ligger som nævit 625 meter over havet, $o g$ et af de hoieste kratere naar 633 meter, saa at hele hoiden er 8 meter. Disse kratere lignede meget de tidligere omtalte, som sees paa kartet vest for Galti.

Derimod havde den tredie gruppe af gamle kiratere nordostligt for Laki (betegnet paa kartet 4 
med hoiderne $639 \mathrm{og} 676 \mathrm{f}$ meget storre dimensioner. Hoiden af laval ved foden er 639 meter, af det ene krater 657 meter, det hoieste 676, hvilket giver en hoide paa 37 meter over den omgivende lavastrom.

Pali Úlfarsdalsskér er afsat gramle kratere, eftersom. Sreim Pálsson amgiver, at her er en klynge af graslose, af lutter smat grus bestatende rundagtige eller halvkugledannede fjeldhumper, hvis udseende viser, at de $\mathrm{i}$ reldgamle tider er dannet ved jordbrand.

Der kan medrette opkastes det sporgsmaal, hvorledes det kan vides, at de ovenfor omtalte kratere er gamle, at ikke ogsat disse har deltaget i eruptionen i 1783. Gamle og nye kratere i denne egn adskilles i regelen let ved den forskjellige konfiguration. Formerne hos de gamle kratere er $\mathrm{i}$ det hele mildere end hos de nye. Siderne er lettere at bestige, dels fordi de er bedakket med noget mos, dels er. slakkerne sammensunkne, saa siderne er mindre steile. Det indre bager er fladere' skaalformet, kraterranden og slakkerygge mellem kratere mindre skarpe, slakkebiterne har mistet en dr. af sine fremstaaende takker og spidser, og de mere afvexlende rode og graa farver paa slakkerne $\mathrm{i}$ de nyere kratere er galaet over til ct mere ensformigt sort hos de gamle.

Ved deme forskjel mellem gamle kratere og nye lader det sig parise, at ikke alle kratere i Lakis ildlinie er nye, at der med andre ord her synes at viere en reldgammel spalte, der er brudt op paany. Allerede under den forste dags vandring var et krater (no. 12 i den sydvestlige rakke) os paafaldende ved sin mere tiljevnede overflade og ved sin javne rand. Men forst efterat vi kom til de nordostligste kratere (no. 29 og no. 30) blev det klart, at disse paa kartet ved en saregén farve aflagte kratere var aldre. I et af dem (no. 32) synes den nye lava endog at have havt udbrud gjennem det gamle kraters bund. Langere sydvestligt i deme rekke (ved no. 21 og 22) trat vi end yderligere fire smat kratere, der tydelig nok viste sig at vere alf reldre dato. Det synes altsaa af disse iagttagelser at fremgaa, at der her efter Lakis spalte ogsaa i aldre tid har fundet eruptioner sted. Da der altsaa efter deme linie findes gamle kratere, og da der, for den nye laval kom, lai grammel lava efter Skaptás og Hverfistljóts render, og da der firemdeles endnu kan sees megen gammel lava paa Nedalland under og foran den ny lava, sandsynliggjor alt det end yderligere den af Sreimn Pálsson udtalte tanke, at der for landnámstid har varet eruptioner i denne egn, og at lavaen ved eruptionen i 1783 ikke fulgte nogen ny vei.

For at give en forestilling om hoideforholdene efter ildlinien og omkring udbrudsstedet hidsattes her de hoidemalinger, som er foretagne ved kraterne. De storre liratere er paa kartet angivne med nummere, og til disse nummere refereres hoideangivelserne. Tallene gaar fra sydvest mod nordost.

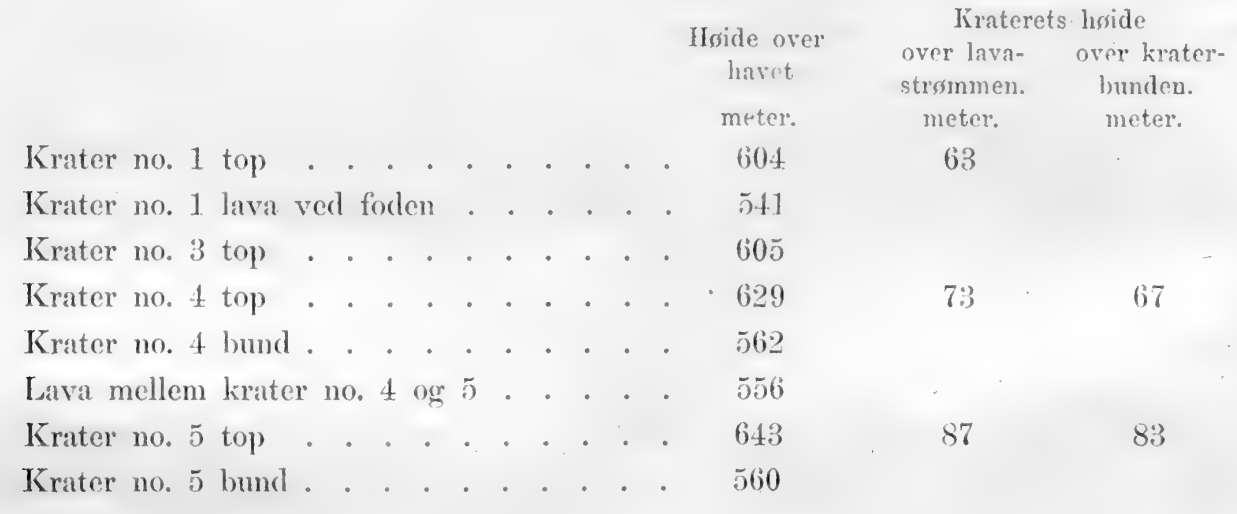


Horide over havet.

meter.

Friaterrand mellem no. 5 og no. 6 . . . . 609

Krater no. 6 bund.

Krater no. 7 top

Krater no. 7 indso

Krater no. 8 top

Krater no. 9 top

Krater no. 10 top

Krater no. 10 bund

Lavastrom ved no. 10

Krater no. 12 bund

Krater no. 13 top .

Krater no. 13 bund

Krater no. 14 top

Krater no. 15 top

Krater no. 16 top

Lavastrom ved Laki

Larastrom ved foden af Blangur . . . . 638

Krater no. 20 top . . . . . . . . 669

Lavastrom ved foden. . . . . . . . 639

Krater no. 21 top . . . . . . . . 681

Krater no. 23 top .' . . . . . . . . 680

Kriter no. 24 top . . . . . . . . 684

Krater no. 25 top . . . . . . . . 676

Krater no. 26 top . . . . . . . . 667

Krater no. 27 top . . . . . . . . . . 660

Lava ved krater no. 28 . . . . . . . 65 อ̆

Krater no. 28 top . . . . . . . . . 713

Gammelt krater no. 29 . . . . . . . . 654

krater no. 30 top. . . . . . . . . . 681

Krater no. 30 bund . . . . . . . . 639

Gammelt krater no, 30 top .. . . . 714

Lava red krater no. 30 . . . . . . . . 652
Kraterets hoide over lava- over kraterstrmmen. bunden. meter. meter.

53

109

58

42

Hvad der her forst falder $\mathrm{i}$ oinene er kraternes ringe hoide. Det er slaghobe, hroraf kun en naar en hoide paa over 100 meter, men hvoraf de fleste er meget under 50 meter, som repræsenterer kanalerne for lavamasser paa milliarder kubikmeter. Medens de andre curopæiske vulkaner som Vesuv og Etna er synlige paa meget store afstande, sa de tjener til landkjending paa lang vei, saa er de islandske vulkaner i denne egn saa lave, at man maa speide efter dem, naar man vil sogre udbrudsstedet.

Efter de foreliggende iagttagelser vil vi forsoge at ajore os rede for, hvad der skede her

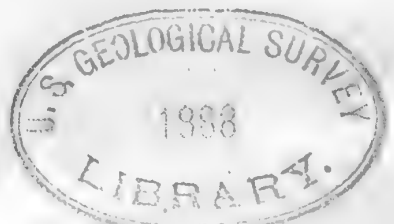


oppe ved udbrudsstedet i 1783. Der er neppe tvivl om, at hvad her er foregalact er en spaltedannelse, at landet er revnet. Alene kraternes beliggenhed paa rad vilde antyde dette, selv om ikke spalten, som pala kiaterkitrtet fremstillet, rar iagttaget paa det sted, hor den shutter paa sydvestsiden af fjoldet Iaki. Den sydvestlige del af spalten er oiensynlig dannet forst og er visseligen det, som Steingrimsson lálder det vestlige udbrudssted. Idet landet revnede, synes fjedlet Laki at have veret stierkt nok til at modstaa og at have sat en græudse for spaltedannelsen mod nordvest. Den egentlige vulkan er selvfolgelig selve spalten, der er bleven fyldt med flydende sten, basalt, der er presset ud over til alle kanter. Selve kraterne, er ikke andet end de slakkemasser, der er blevne liggende omkring de punkter, hvor spalten har spyet kiraftigst. Udbrudet synes saaledes at repræsentere dannelsen af en basaltgang af samme lengde som spalten, og hvis vi kunde trenke os alle kraterne borte og et snit igjennem jordens overflade under kraterne, saa vilde vi efter al sandsynlighed fata se en steiltstaaende basaltgang med horizontale soiler.

At der har fundet eruption sted af mange liratere paa engang fremgaar tydeligt nok deraf, at de tre bunder, som var oppe paa Kaldbakr den 16de juni 1783, saa 22 ildsoiler i "Úlfarsdalr", hvilken dal, som det vil sees af kartet, ligger i samme retning fra Kaldbaki som den sydvestlige kraterrakke. At damnelsen af en saa voldsom spalte har været ledsaget af jordskjæelv, larm og bragen, saaledes som de samtidige beretter om det, er ikke at undres over.

Damnelsen af spalten nordost for Laki or yngre og fandt sted i de sidste dage af juli, og det siges, at larmen var ikke mindre end ved det vestlige udbrudssted. Udbrudsstedernes beliggenhed og et blik paa kartet vil forklare, hvorfor lavaen den ene gang tog reien mod sydvest til Skaptá og den anden gange mod sydest til Mrerfisfljót.

Niveauforskjellen paa lavastrommene er i det hele ikke stor langs kraterrækken. Lavastrommen stiger i den sydvestlige rekke op mod Laki; ved krater no 1 ligger den 541 meter over havet og stiger saa til 556 meter (mellem no. 4 og 5), 580 meter (ved no. 10) og 585 meter sydvest for Laki. Nordost for Laki ligger lavaen (ved krater no. 20) 634'meter, (ved no. 28) 655 og (ved no. 31) 652 meter over havet. Den hele niveauforskjel paa den omtrent 20000 meter lange strækning. er altsaa kun 114 meter. Mod nord sænker laraen sig meget langsomt, hvilket fremgaar deraf, at strommen ved de nordenfor liggende gamle kratere ligger 625 meter over havet. Paa disse vide marker har lavaen altsaa udbredt sig temmelig jevnt.

Maalingerne for lavastrommens hoide i Skaptás rende - ved Olduskér 444 meter, ved Búland 135 meter og ved Ásar 0 meter - giver et fald paa respektive 1 paa 72,1 paa 78 og 1 paa 66 for strekningen mellem disse steder, men tages den hele lavastroms langde, 60 kilometer, og beregnes faldet efter lavaens hoide red Laki, 585 meter, faes et fald paa 1:103, eller en skraaning paa 31 minuter eller lidt over $1 / 2$ grad. Tages niveauforskjellent, 600 meter, mellen nordostre kraterrakke ong endepunktet af lavastrommen efter Hverfisfjót og sammenlignes denne med liengden, 36 kilometer, saa faaes et fald paa 1 paa 60 , eller en vinkel paa 57 minutter eller næer en grad. Den vestlige strom har altsaa flydt med en skraaning paa $1 / 2$ grad, den ostlige med 1 grads skraaning i gjennemsnit.

Mellem de tidtnrevnte fjelde Laki og Blængur begyndte efter Pálsson for 1783 en dal, som hed Vamairdatr. Den blev storre og storre mod sydsydvest henimod Varmárfell, hror den vendte mod vestsydvest mellem Úlfarsdalsskér paa den ene side og Hrossatingur paa sondre side. I kort afistand fra Skaptá nataede den til gabet af Úlforsdutr, hvilken dal her vest for Úlfarsdalskér gik i nord og syd, adskilt fra Skaptás rende ved en lav og ganske smal ryg bestaaende af forbrændte 
annelse, im ikke tsiden af m Steinerkt nok vulkan esset ud blevne repreos alle andsyn-

k derat, ursdalre, Ivestlige larm $\mathrm{og}$ juli, og eliggen1 Skaptí

Lavater over sydvest $o g$ (ved strækur deraf, sse vide

B Búland , 66 for teregnes paa 31 krater36 kilod. Den kraming

lal, som vendte

I kort ér gik i brendte

hraunklipper. Baade gjemnem Úlfarsdaly og gjennem Varmárdalr gik der store elve, hrilke, strax efter at dalene var forenet, sammen udgjod sit rand i Skaptŕ. I begge disse dale rar der. for udbrudet godt beite. Navnet Varmárdalr synes at antyde, at her tidligere har varet varme kilder, skjont folk i 179., efter Pálsson formedelst mangel paa agtpaagirenhed, intet vidste at berette om gamle hverer, svovlkilder eller lava i denne egu. Pślsson antager, at udbrudet er begyndt omtrent midt i Varmárdalr. Senere er hele den sydrestre rekke kommet ibrand, og hrert krater har udgydt sit forraad af glodende lava gjennem sarskilte render til Varmárdalrs elv, der senere har befordret lavaen gjennem en hovedrende til Skaptá, der har fort dem videre til beboede egne. Efterhaanden er saavel Skaptís rende som den sydvestlige del af Varmárdall bleven proppet fuld af lava, men kraterne vedblev at sprutte. Lavaen har da efter Pálssons mening i form af smaa bekke krobet mod syd over de saakaldte Hrossatíngar, der nu nesten helt er bediekkede af lava, hen til den nu helt med lava opfyldte Hrossatúngná og tilsidst er den fira nordnordost til sydsydvest gaaet langs

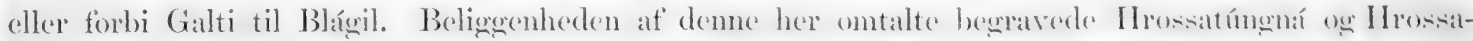
tíngur kjender jeg ikke noiagtigt. Maaske er de gamle kratere sydligt for Varmárdalr en del at Hrossatúngur, og maske har Hrossatúngna strommet mod sydvest i en dal eller forsankning mellem disse kiratere og Olduskér. Af den lava, som strommede over Hrossatíngur, bler da en ny lavastrom, som styrtede frem efter Hrossatíngnás rende og helt optorrede elven. Denne strom gili videre mod sydvest hen til Hellisá og fortrængte denne elv til den ostlige side, men fulgte forovrigt denne elvs rende hen til Leidolfsfell, hvor den igjen forenes med Skaptárendens lava.

Paa vor vandring omkring udbredsstederne er vi ikke komne lrengere mod nord og nordost, end de afsatte hoidemaalinger viser. Lavaens grendser mod nord og elvenes udlobssteder fira jokellen er derfor alt tegnet efter bedste skjon, saaledes som vi antager, at det hele kin ligge.

Den sidste nat, vi opholdt os i deme egn, natten mellem den 17de og 18de august indtraf klarveir med frisk kulde, saa at teltet om natten fios stivt som pap. Solen belyste herligt den megtige Skiptárjokull, da vi om morgenen forlod demue merkverdige cogn, hror en expedition, berdre udrustet med mad og kleder end vi var, vil kumne anstille langvarigere og mere detaillerede undersogelser med stort geologisk og geografisk udbytte. Veien tog vi tillage over Miklafells ryg og kom ogsaa ned til den ostlige lavastrom. Veien gik videre paa ostsiden af Kaldbakr, et megtigt fjeld bestaacnde af palagonittuf med benke af basalt. Horgsa har her par ostsiden af Kaldbakr udskaaret et dybt Gjel, Hergsághlifr. I sidegjel her iagttoges jettegryder. Udimod kysten sanes et

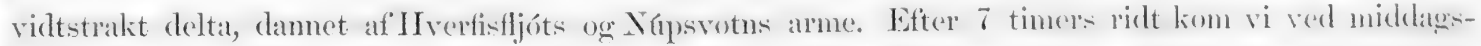
tider tilbage til Horgsdalr igjen.

- Idet den flydende lava fulgte elvenes render frembragte den naturligris stor forandring i alle vasdragene, idet den dels opfyldte hele elveleierne, dels tilstoppede tvarelvene. Renderne for de storre elve, Skaptá, Hzerfisfioot, Steinsmýrarfljót, Sydri Ofara og lifri Ofara samt tildels Kïdafijót blev mer eller mindre udfyldte. Stephensen nevner folgende clve, som bleve tilstoppede: par Medalland: Fedgaquísl, Landá, Lingaquísl, Mclquísl, paa sydsiden af Sida: Holtsá, Fjarbará og Laxá og ovenfor bygden folgende bielve til Skaptá Varmá, Hrossatungná og Hellisá. Enkelte af disse elve, som til exempel Varmá, er helt forsvundne under lavaen, andre, som elven ved Holt, Holtsá, har dannet en liden indso, idet lavaeu stopper for mundingen, og forovrigt har vandene sogt sig veie mer eller mindre forskjellige fra de gamle. Foran Hverfisfljots lavastrom er der paa Stephensens kart afsat en stor vandausamling; af deme opsteg der i 178t, da Stephensen reiste derover, rog paa de fleste steder, og paa nogle steder var vandet saa hedt, at man neppe 
kunde taale at holde haanden deri. Han bemerker, at det var swrdeles ubehagelight at ride fod for fod over tre stive mile $\mathrm{i}$ dette hede vand indhyllet $\mathrm{i}$ damp. Den her angivne langde for deune randansamling par den strekning, hor nu gaardene Slettabol og Hruni staar afsatte paa kartet, synes rel stor. Allerede i $1794 \mathrm{var}$ de her omhandlede opdremmede vande forsundne. En temmelig stor elv kom 1794 ud af laraens langste odde mod syd, hvilken kaldtes Eldvatn. Ogsaa fra Skaptálavaens sydligste ende kom der ud et Eldvan, der i 1784 vel rog, men ikke kunde kaldes hedt. Medens dette rand enduu var lunkent, sogte en ualmindelig mengde orreter op hid.

I det folgende atr var elvene omkring Sida efter Steingrimsson mindre end ssedvanligt, ogsaa $\mathrm{i}$ de elve, som kommer fra Skaptírjokull. I denne jokel hortes strerke knald og larm.

- De af Lakis kraterrekke udsendte lavaer er samtlige basaltiske lavaer. De er morke af furve, fulde af blererum, men hyppig sees i den morke lava et hvidt mineral, der under mikroskopet viser sig at reve plagioklas. Olivin kan ogsaa nu og da erkjendes. Under mikroskopet viser denne lava overalt samme mineralogiske sammenswetning, men der er nogen forskjel i struktur, eftersom mineralierne har krystalliseret med ontrent samme dimensjoner, eller med forskjellige dimensjoner, saa strukturen bliver porfyragtig. Paijkull, der har analyseret lava fia dette udbrud, har fundet folgende sammensatning:

\begin{tabular}{|c|c|c|c|c|c|c|c|c|c|c|c|c|c|}
\hline Kisclsyre & & & & . & & & & & & & & & \\
\hline Terjord & & . & & . . & & . & & & & & & & \\
\hline Jernoxydul & & . & & . & & & & & & & & & \\
\hline Kalk. . & . & : & & . & & & & & & & & & \\
\hline Magnesial & . & . & . & . . & & & - & & & & - & & \\
\hline Kali . & & . & . & . & & & . & & & & & & \\
\hline Satron & & . & & . & & . & & & & & & & \\
\hline
\end{tabular}

Den mikroskopiske undersogelse af den basisaltiske og anamesitiske lava fra dette udbrud viste folgende:

Lava ifra Laki, taget ved et krater no. 30 nordostligt i rekken, bestalar af plagioklas, augit og sparsomt olivin, porfyragtig udskilte i storre krystaller i en grundmasse, bestatende af mindre krystaller af de samme mineralier samt magnetit og en mellem krystallerne indeklemt basis.

Lava fra Lakis vestre strom red Blágil, $446 \mathrm{~m}$. o. h., bestar af plagioklas, augit og olivin i krystaller af forskjellige dimensioner samt af en i kanterne med dyb brun farve giennemskinnelig basis, der imidlertid som oftest er nesten ganske ugjennemsigtig.

Lava fra Lakis vestre strom ved Skaptardalr. Storre og mindre krystaller af plagioklas og augit, sjelden olivin, ligger i en med magnetitkrystaller opfyldt temmelig tilbagetrængt brun glasbasis.

Lava fra Lakis ostre stroms sydligste ende, ikke langt fra Hruni, viser en anamesitisk sammenswetning, idet krystaller af plagioklas, augit og olivin natr op til dimensioner paa $1 \mathrm{~mm}$. Imellem krystallerne ligger der en ved brune korn afglasset basis, der oftest er ugjennemsigtig.

Eldre lava fia gammelt krater ner Laki viste en basaltisk sammensatning som lavaen af 1783, idet storre og mindre krystaller af plagioklas, augit, olivin og magnetit med en kornet, tilbagetrængt basis sammensietter stenen.

De slakker, der danner selve kraterne, viste en anden sammensatning $\mathrm{i}$ mineralogisk henseende, idet en rod glas er hovedbestand, i hrilken krystaller af plagioklas og augit ligger udskilt. 
Slak af 178:3 fra krater ner Laki viser i prepanatet makroskopisk en teglstemrod farve. Thder mikroskopet sees $\mathrm{i}$ den af mamge og store blarerum opfidelte slak en rod til guldgul glas som hovedbestanddel, i hvilken krystaller af plagioklas on angit forekommer udskilte. Den glas, som udgjor hovedmassen af stenen, skimner paa mange steder igjemnem med en smuk rod, langs blerermmene guldgul farve, men pala andre steder er den ugjememsigtig. Plagioklasen er tilstede i storre og mindre listeformede, rektangulare og megehmessigt begrandsede krystaller og optrseder ligesom atugiten i ikke ringe mangde. Magnetit synes ikke at forekomme, ligesalidt som olivin er parist med sikkerhed $\mathrm{i}$ slakkerne.

On et provestykke af slak eller lava, som Stephensen havde taget i en hule, fortseller ham folgende: Apotheker Myhlenstch glodede 10 kvintin af stykket, pulveriserede det og behandlede det med vitriololic og fortyndede oplosningen med s dele vamd. Oplosningen galv et stykke poleret jern en smuk kobberfarve. Kobberet blev udfieldt med jern og veiede 15 gram. Ligesan omtales det, at der af et stykke almindelig lava vegtig $31 / 2$ kvintin blev udskilt $33^{1} / 2$ gran kobber. Efter disse prover skulde lavaen vare kobberholdig i ikke ringe grad. Hr. bergkandidat Roschor provede i den anledning et par af de hjembragte lavaprover pal kobber, men der fandtes ved de noiagrigste prover kun de svageste spor af dette metal. Hine gamle underogelser beror manke paa en mistorstanelse.

- Maales lavastrommens lengde fra lrengst i nordost og indtil Medalland, sala bliver den hele lengde, som det sees, ontrent 80 kilometer, men for den ostlige arm 45 kilometer.

Wladeindholdet af det areal, Javaen dekker, anslog jeg oprindelig til 500 kvadratkilometer, men efterat kartet er fierdigt, og lavien aflagt pata samme, sknkde jeg tro, at 900 kvadratkilometer konmer det virkelige forhold nermere. Herved ar imidlertid at bemerke, at lavaens nordgrendser er usikre.

Kjendte vi den midlere mregtighed for lavaen, sata kunde dens kubikindhold bestemmes. Om lavaens megtighed bemserker Holm (pag. 19), at den ved Sksilarfjall havde en lodret hoide af 70 favne. Stephensen siger, at den hoide, til hrilken lavaen er opdynget paa den flade mark, er meget betydelig, fornemmelig udenfor Skálarfjall; dog skulde han tro, at naar man ansæetter dens hride til 100 fod, sattes den endog for hoit, da den overhoved par den flade mark ikkun er 20 til 30 fơd hoi. Hertil bemærker Pálsson, at dens hoide efter anstillede peilinger pala mange steder har overgataet 100 fod, og at lavaen senere er sammensunket til $2 \%$ af den oprindelige hoide.

Vanskeligheden ligrer $\mathrm{i}$ at fau et bestent tal for den midlere megtighed af en lavastrom, der har flydt over et saa kuperet terrain. Ved de sydlige dele af lavastrommen, hvor deme ligger som on kage paa det flade land, kan giemnemsnitsmegtigheden neppe anslaaes til mere end 10 meter, ialfald ikke ner enderne. Men det slatr ikke feil, at oppe omkring kraterne og i de af lavastromme udfyldte dalforer, svelgr, gjel og glufere er megtigheden meget storre, og de samtidige forfattere forsikrer, at Skaptárglúf har havt en dybde af 4 til 500, ja vel 600 fod (Magnus Stephensen), or deslige render er ei alene udfyldt, men lavaen har efter beretningerne omflydt hoie bjerge paa siderne.

Maaske turde en midlere mregtighed paa 30 meter ikke varet noget urimeligt tal. Under disse forndsretninger vil den udspyede lava udgjore 27 milliarder kubikmeter sten, der vil veie omtrent 67 milliarder tons. Man kan damne sig en forestilling om, hvad dette vil sige, ved at trenke sig lavaen samlet til (n whye firkantet blok. Den vilde da damne en blok en ny norsk mil (10 kilometer) 
lang, 1/2 ny norsk mil (5 kilometer) bred og .540 meter eller 1721 fod hoi. Lyell har sammenlignet indholdet af Lakis lavastrom med kubikindlholdet af XIont Blane, men deme sammenligning er for voldsom, ialfald hris vi tænker. os Mont Blanc med en rimelig skraaning fortsat ned til havets niveau. Selv om vi: forudsetter en saa stor midlere skraaning som $45^{\circ}$, og vi forestiller os Mont Blane somi en firsidig 5000 meter hoi pyramide, saa vil demes side ved havet udgjore 10 kilometer og kubikindholdet bliver $\frac{10 \times 10 \times 5}{3}=166$ kubikkilometer eller 166 milliarder kubikmeter. Lavamassen, paa 27 milliarder $\mathrm{m}^{3}$, vil, som det let sees, udgjore en terning med 3000 meters side.

- Det kan ikke slaa feil, at naar en vulkan udsender lavamasser, saa maa der under jordens overflade fremkomme tomme rum, der staar i forhold til de udsendte lavamassers volum. Hris de fremkomne tomme rum ikke kan staa uden understottelse eller udfyldes ved nye tilstrommende lavämasser, saa maa de styrte sammen, og der kan vel neppe vere tvivl om, at en sammenstyrtning af saadanne. umaadelige hulerum vil frembringe jordskjæelv, og hvis hulerummene ligger ner dagen, saa vil disse indstyrtninger give sig tilkjende i dagen som dislokationer og sprekker. Den bevagelse, som der nodvendigvis maa vere i lavaen under udbrudet, idet den trylkes ud imod den aabnede spalte, synes ogsaa at maatte give anledning til, at nogle tomme rum fyldes $o g$ andre tommes, og indstyrtninger synes da ogsaa at matte finde sted under den tid, da lavaen skifter plads. At damnelsen af selve den vulkanske spalte, idet jorden brister, maa vere ledsaget af voldsomme jordskjælv, er: ogsaa forstaaligt. Baade ved begyndelsen af det forste udbrud $\mathrm{i}$ juni og under udbrudet, ved, hrilket Hverfistjjots rende fyldtes, omtales ogsan jordskjelvene som meget voldsomme, og Steingrimsson siger, at larm og dunder var ikke mindre ved det ostlige end ved det vestlige udbrudssted.

Aaret efter udbrudet, den 14de-15de til den 16de august 1784, indtraf de voldsomste jordskjælv, som overhovedet er iagttagne paa Island. Disse jordskjæelv var aller strerkest i Ánessyssel, men var folelig vidt og bredt paa Island. I Rangárvallasyssel blev 23 gaarde fuldstændig odelagte, og desuden faldt 94 huse paa forskjellige gaarde. I Arnessyssel bler 69 gaarde fuldstrendig odelagte og 372 gaarde og 11 kirker meget beskadigede. Latinskolen i Skálholt og de fleste vaaningshuse faldt ned, men domkirken stod. Fjeldene brevede og rystede, saa at gresdiekket paa siderue bley revet fra underlaget og gled ned; paa Vestmannaeyjar blev Here fuglebjerge odelagte, og fra et lidet fjeld Vordufell paa Skeiour faldt 36 stenskred. Varme liilder forandredes, torredes ud paa et sted og brode op paa andre steder; nogle nye bler dannede og. gamle forsvandt; red Geysir dannedes 35 nye kilder: ; flydende og stillestanende vande bleve meget oprorte og hride som melk, og floderne saa ud som malstromme. Ved Tórfastadir i Biskupstungur blev en sump torret ud, medens en anden ved Ásakot forvandledes til en indso, og paa mange steder slog jorden dybe revner.

Ved strdene blev mennesker og kreaturer kastede omkuld, og en mand, som skar grrestorv paa en vaad eng, stod skiftevis i knæerne i vand eller paa tort land, alt efter jordskjelvets bolgebevagelse. Mange bleve begravede under husenes ruiner, men meget faa mistede livet.

Dette jordskjælv indtraf, som vi ser, aaret efter det voldsomme udbrud fra Lakis kraterrekke, og det var voldsomst i Árnessyssel og Rangárvallasyssel. Efter Steingrimsson var

*) Stephenssen beretter, at Geysir efter jordskjælvet spruttede en usædvanlig mængde vand, hvortil Pálsson bemærker, at dette modstrider den almindelige beretning i nabolaget, der endog paastaar, at den aldrig har sprudet saa hoit som forhen, smen des mærkeligere er den i nærheden opkomue Strokkur, der blot og alene spruder vind». Nintildags spruder Stokkur som bekjendt vand. 
joidskjalvene: ved Prestbakki lette den 14de og 15de samt 23de august, og han tilfoier, at det er

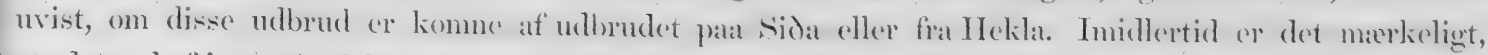
at dette heftigste jordskjæly, som er iagttaget paa Island, indtreffer aaret efter det ndbrud, der har udsendt de storste lavamasser. Skulde hint voldsomme jordskjelv antyde en sammenstyrtning af de temme rum, der er fremkomme ved udpresningen af hine cnorme kvantiteter lava? It jordskjæelvet var voldsomt i Árnes- og Rangárvallasyssel og let par Sida, er intet positivt bevis mod; thi de underjordiske reservoirer for lavaen kan jo have ligget i nogen afstand fra vulkanen.

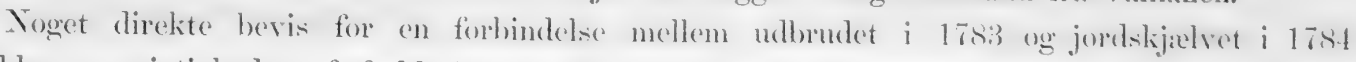
findes ikke, og rigtigheden af forklaringen af dette sidste ved sammenstyrtning af de tomme rum, fremkomne red de udspyede lavamasser, lader sig ikke paarise, ligesom vi jo ogsaa endnu mangler en fuldt tilfredsstillende forklaring over de vulkanske fromomener i det hele.

Fem aur senere i 1789 sank under starke jordskjecty red píngrellir hele landet mollem

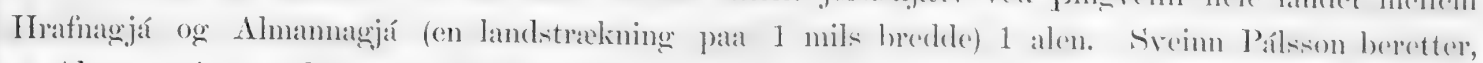
at Almamagjás sondre varg er sunket 4 til 6 alen paa sine steder. Denne sankining af land srones at antyde, at der $\mathrm{i}$ jordens indre gives hulerum, som skal udfyldes.

De talrige sprakker eller gijer paa Island viser, at her ofte finder sankninger af land sted, og det synes da rimelight, at disse girier med deres sankninger giver tillijende, at de tomme rmm i jorden, fremkomne ved lavamassernes udtommelse, styrter sammen.

I forbindelse hermed kan anfores folgende, som Steingrimsson beretter:

"Pata den sterke frest i januar (16st) fulgte svere jordrystelsere, dog af langt anden heskaffenhed end hine under selve udbrudet. Efter som disse sightnedes, horte mam paa mange stedor her paa Sioa adskillige lyd i jorden mest som greden, hunds uren, brolen o. s. v. Engang da jeng var ret i fierd med at drive dette tillagee som noget, der var et foster af overtro og rang indlbildning, og i selskab med 2 andre sad i min stue, horte vi alle sammen, ligesom en oxe hrolede langt borte, som dog ei kunde vere i denme atrets ticl, da alle kreaturer af det slags fores para stald. Midt i det at vi snakkede om, hror dette kom fra, hortes et andet, mange gamge sterkere end det forste. Dette syntes at begynde mange hundrede skridt nede i jorden, fortes mere og mere dogr stedse sragere opad, til det endelig bler til intet lige under gulvet, vi stod para, hrilliet $\mathrm{i}$; ammme moment fandtes sagte at berage sig eller sitre.

Det var tydeligt, tilfoies der, at denne lyd kom af den tomhed, som var $\mathrm{i}$ jorden efter ilden og dens udbrud.«

- Som bekjendt har man i de senere aar efter det store udbrud i Krakatoa i Sundastredet iagttaget en eiendommelig gloden af himmelen, der har ledsaget solens opgang og nedgang. Denne glod bler allerede i september $188: 3$ iagttaget i Indien og her i Norge i november 1883.

Almindeligvis forklares deme himmelglod af det fine vulkanske stov, der er udkastet af Krakatoa eller andre vulkaner langs Asiens ostkyst. Professor Fearnley har (Naturen april og mai 1885) omtalt, hvorledes fint pimstensstor kan i manedsvis holdes svevende $\mathrm{i}$ atmosferen, ligesom han har regnet nd, at storrelsen af de over Kristiania svevende pimpstenpartikler er i tvermaal $2 \frac{1}{2}$ tusendele af en millimeter ( $21 / 2$ mikron), videre at der for at opfylde hele jordens atmosfere med pimpstenstor i forhold som her i Kristiania kun vilde udfordres 1 million kubikmeter stov. Dette er kun $1 / 27000$ af de masser sten, som Lakis kratere efter min beregning har udspyet.

Interessant er det nu, at lignende fienomener er iagttaget i Danmark og paa Island efter udbrudet i 1783, og at man allerede da satte deme himmelens farve i forbindelse med udbrudet. 
I Holms skrift (On . Tordbranden i 1783 heder det sataledes: $\$ H_{0 r}$ i Steland og Kjobenhavn fandt man i begyndelsen af juni solens overordentlige rodhed til den sde august isier, men hele juli saadan dunst og stov i luften, som dog var klar i sig selv, at man kunde aldeles ikke se solen længer om aftenen end til kJokken 8 i 9 , og saa var det hver morgen, og ikke heller skinnede den saa klar om middagstiden og viste sig ligesaa rod om aftenen; det samme var at iagttage om manen og stjernerne. Den hoilarde hr. professor Kratsenstcin sagde, at det var af jordild paa Island, som dog er merkværdigt, da Island bliver snart 300 mile herfra (i N $\mathrm{N}$.)

Videre heder det: Paa jorden faldt et slags hvidgraangtigt stov, og paa marken tidt ved nattetider en blaa eller blaalighvid taage, som gav af sig et slags dunkel ild eller svovlrogs lugt, $o g$. da det slags taage mærkedes, faldt her liden natdug eller snart ingen imellem; alt dette blev fundet $\mathrm{i}$ Tyskland, Holland $\mathrm{og} \mathrm{i}$ andre lande; endnu fir 8de august til 16de september har man bestandig seet solen rod morgen og aften.« 13de, 27de, 28de, 29de og 30te november og 11te december var solen endnu noget rod; ligesaa kunde man mærke noget lignende 12te og 13̧de januar samt 11te februar 1784 .

Lignende pragtfulde farver som de i sidste aar her i Kristiania iagttagne beskrives ogsaa i 1783 fra Island. Her hidsættes forst professor Fearnleys beskrivelse af fænomenet i Kristiania den 12te januar 1884, og saa provst Steingrimssons beskrivelse fra Island, 100 aar reldre, den 24de december 1783.

》Sxrdeles smukt var fanomenet lordag den 12te januar (1884). Himlen var klar; kun i horizontens brunlige tone sporedes virkningen af et tret taageslor, hvorigjennem solen ud paa eftermiddagen viste sig rod. En halv time efter dens nerlgang saa man en pragtfuld dremringsbue med de vanlige farver: lavest - gjennem taagen - kraftig brunt, derover dybt orange, saa et rent gult, der igjennem xblegront gik over til blaalighvidt. Naar undtages enkelte i forstningen solbelyste striber af fjærskyer, der efterhaanden morknede og tegnede sig skarpt mod den lyse baggrund, var himmelen tilsyneladende klar; men i lobet af 10 à 15 minutter antog den blaahvide zone den eiendommelige fine rosenfarve, hrormed ogsaa frenomenet den 30 te november begyndte. Kl. 4 t. $8 \mathrm{~m}$. strakte det rode sig i et bredt belte over en betydelig del af den sydvestlige himmel. Det naaede en hoide af mindst 30 grader, og i buens eller segmentets vestre del straalede Venus som en glimrende smaragd, hvis lysegromne farve manske var en virkning af kontrasten mod den rode himmelgrund. Det smukke rode skin var klarest omtrent 4 t. $15 \mathrm{~m}$., dog langt fra saa strerkt som den 30te november. En halv time senere saaes det endnu tydeligt i 10 graders hoide, men forsvandt i den tiltagende taage kl. 4 t. $50 \mathrm{~m}$.

Noget lignende synes Steingrimsson at have iagttaget, naar han skriver: „Den 24de december 1783 var lklart og stille veir en tid lang for solens nedgang, da en tyk sky samlede sig nederlig i dunstkredsen lige over Kirkjubejar klaustrs fjeld, hror den af mangfoldige blev iagttaget. Den saa akkurat ud som billedhuggerarbeide og lignede et langagtigt eller halvmaanedannet skildt, omtrent som man ser paa en del fartoiers bagstavn over kahytvinduerne. Den ophoiede eller lyseblaa del i midten var omgiven og besat med en krands bestaaende af mangfoldige kngler, omdreininger, grene af morke, hoirode, sorte, rustede gule, ansigts- og saffranfarver foruden utallige sammensatte, der ei kan beskrives. Man betragtede i nogen tid denne sky, indtil den, uden at forandre sted, forsvandt $\mathrm{i}$ et oieblik ret ved solens nedgang. Ligedanne særsyn er seet i samme vinter paa to lamgrt fraligrgende steder i landet og blev af nogle ansect som forvarsel for den forlgende folkedod. Under selve udbrudene var som for berort solen sjelden at se gjennem den svovlede rog 
og taige, og aldrig anderledes end en blodrod, dunkel klode. Forst i decembor 17s:3 hegrndte efter Steingrimsson al uklarhed at tage af, og forst da fik sol og mane sin rette glands i klar luft.

- Steingrimsson gjor den bemrerkning, at ligesom det forste udbrud skede omtrent verl forste spring, saa har man ligeledes siden efter fornummet, at vulkanen var mest urolig i ny$o g$ fuldmaane.

Det er af denne grund vrerd at sammenligne tiderne for de voldsomste udbrud med tiderne for nymaane og fuldmaane.

Efter almanak fra 1783 indtraf nymane og fuldmaane i 1783 par folgende tider efter Kjobenhaons tid:

\section{Nymane.}

31 te mai kl. 2.57 f. m.

29de juni kl. $5.53 \mathrm{c}, \mathrm{m}$.

29de juli kl. 8.48 f. m.

27 de august kI. 11.27 c. m.

26de september kl. 1.19 e. m.

26de oktober kl. 2.2 f. $\mathrm{m}$.
Fuldmane.

15 de juni kl. 1.21 fo $\mathrm{m}$.

14de juli kl. 7.50 f. m.

12 te august kl. 3.10 e. m.

11 te september kl. 0.28 fo m.

lode oktober kl. 0.21 e. m.

Laki ligger efter Gumnlaugssons kart $30^{0} 45^{\prime}$ vest for kjobenhavn, folgelig er tidsforskjellen 2 timer og 3 minuter; men da det i denne undersogelse ikke kommer an paa minuter, kan tidsforskjellen regnes til 2 timer, og afrundes Kjobenhavns tid til nermeste hele time, saa vil dette være tilstrækkeligt til den folgende sammenligning.

Steingrimsson ontaler 4 hovedudbrud fra de vestlige kratere og 4 fra de ostlige.

De forste jordskjælv mærkedes 1ste juni, og sde juni kom ilden forst op. Pálsson sammen_ fatter Stephensens og Steingrimssons beretninger saaledes:

Andet udbrud fra Skaptá sattes af Steingrimsson til 19de juni, af Stephensen til 18de samme maaned. Tredie udbrud srettes af Steingrimsson til 29de juni, fjerde til 14de juli. Han satter de forste rogstotter fra de ostlige kratere til den 29de juli, Stephensen til den 28de. Forste udbrud af Hrerfisfljóts rende angiver Steingrimsson til 7de, Stephensen til 9de atugust; andet, tredie og fjerde udbrud var efter Steingrimsson 1ste september, 10de og 25de oktober.

Sammenstilles de saaledes angivne datoer for hovedudbrudene med stedets tid for nymane og fuldmaane, faaes:

\section{Maanen.}

31 te mai kl. 1 f. m. nymaane.

14de juni kl. 11 e.' m. fuldmaane.

29de juni kl. 4 e. m. nymaane.

14 de juli kl. 6 f. m. fuldmàane.

29de juli kil. 7 f. m. nymaane.

12 te august kl. $1 \mathrm{f}$. $\mathrm{m}$. fuldmaane. 27 de august kl. 9 e. m. nymaane.
Vulkanen.

1ste juni mærkedes forste jordskjælv.

8 de juni kl. 8 f. m. kom ilden op.

18de jumi (efter Stephenssen 19de) 2det udbrud. 29de juni 3die udbrud.

14de juli 4de udbrud.

29de juli (efter St. 28de) forste rogstotter fra de nordostlige kratere.

Fde august (efter St. 9de) forste udbrud fra ost. 
Ma ancn.

10de septemper kl. 11 e. m. fuldmaane.

26de september k. 11 f. m. nymaane.

10 de oktober kl. 10 f. m. fuldmaane.

25de til 26de oktober kl. 12 nat nymaane.

Som man ser, kommer vi til folgende resultat: Der er fra 31te mai til 25 de oktober 11 ny- og fuldmaaner; 10 facer i vulkanens udbrud er betegnede som de voldsomste eller de vigtigste. Af disse falder de fem paa dagen for nymane eller fuldmaane. Begyndelsen af udbrudet, der gay sig tilkjende ved jordskjælv, kom dagen efter nymane.

Endskjont udbrudene altsaa oftere træffer sammen med ny-eller fuldmaane, end de efter sandsynlighedsberegningen paa forhaand skulde antages at gjore, saa tor man neppe af disse tal slutte til en forbindelse mellem manens facer og udbrudets. For imidlertid at undersoge dette forhold nermere, har jeg beregnet manens alder paa 47 datoer for begyndelsen af udbrud og for voldsomme udbrud af islandske vulkaner samt for jordskjælv par Island, alt efter de dage og aarstal, som Thoroddsen angiver i sin Oversigt over de islandske Vulkaners Historie fia Aaret 1700 indtil nu." Resultatet af denne undersogelse har varet, at det ikke lader sig paavise nogensomkelst forbindelse mellem nymaane eller fuldnaane og vulkanernes udbrud. Vulkanerne begyinder sine udbrud og raser voldsomt $\mathrm{i}$ alle manens aldere, og tiden for nymane eller fuldmaane udmarker sig statistisk ikke $\mathrm{i}$ henseende fremfor nogen af mamens andre facer.

- Udbrudet af Lakis kratere rar en nationalulykke for Island. Grresvrexten forkrobledes, kreatureme omkom i tusenvis og sygdomme og hungersnod rasede blandt menneskene og bortrev i det folgende aar en femtepart af befolkningen. Den skade, som lavaen direkte forvoldte ved at oversvomme garode $o g$ land, var forholdsvis mindst. Stephenssen angiver, at 8 gaarde helt er odelagte, saa at de aldrig mer kan beboes, og 29 gaarde er mer eller mindre beskadigede, dog ikke mere, end at de maske alle med tiden blive befolkede. Af disse var i 178415 ode. Pálsson bemerker imidlertid, at det af Holm angivne tal, 89 gatrde, der bestandig vil lide ved dette udbrud, ikke er saa meget overdrevet.

Allerede ved det forste udbrud faldt der, som tidligere omtalt, aske, sand udover det omliggende land, fornemmelig over Sioa og Fljotshrerfi, saa at der ikke kunde sees nogen redning for kreatureme. Luften blev mere og mere opfyldt med aske, sand og svovlstov samt med rog og vanddunster, saa at den blev mere og mere ubehagelig, stinkende og usund. Den urene luft opslugte solens lys og varme, og ved midtsommers tid indtraadte en gjennemtrængende og unaturlig kulde, saa at der endog indtraadte stærkt snefald den 11te og 21de juni. Nasten alle udbrud var ledsagede af usædvanligt store hagl, store som spurvereg, hvilke foraarsagede megen skade paa markerne, ja som ner havde slaaet mennesker og kreaturer ihjel. Undertiden indtraadte stæerk slakregn til endnu storre skade; thi den blandedes med den nedfaldne sand og aske, saa at markerne blev overdragne med et slags sort dynd ligesom blek, der forgiftede græs og urter og gjorde vandet stinkende og udrikkeligt. Ogsaa regnen var blandet med svovl« og aske og sviede stærkt $\mathrm{i}$ oinene, samt foraarsagede svimmel i hovedet $o g$ store smerter, hvor den faldt paa det blotte legeme. Rogen bedrekkede landet hele uger og maneder, saa at de sofarende ikke kunde faa det isigte, forend de laa tat under kysten. 'Taagen eller rogen hindrede fiskerne $i$ at drage ud, og sommerfisket blev derfor ubetydeligt. Rogstotterne steg om sommeren 1783 saa hoit, at folk kunde se dem 30 
mil borte som store skybanker i luften. Den samme tykning i luften holdt ved til midt i september samme aar, men efter den tid blæste mest nordlige vinde, der medforte en klarere luft.

Det anfores som en mrerkelighed, at om sommeren 1783 har de nordlige vinde altid fort den storste tykning over landet, tvertimod hvad man skulde formode, nemlig, at den fra landets sydside opstigende rog maatte adspredes af nordlige vinde og fores ud over havet. Ligeledes anfores det om de sydlige vinde, at de, skjont de drev rogen fra udbrudsstedet ind i landet, dog medbragte klarere luft $\mathrm{og}$ veirlig. Tykningen $\mathrm{og}$ stovtage holdt ved paa Island hele sommeren 1783 , men om vinteren var den sjeldnere, men blev dog iagttaget lige til juli 1784. Endog paa langt borteliggende steder iagttog man $\mathrm{i}$ vinteren 1784, at sneen ovenpaa har varet belagt med meget fint. askestov.

Holm beretter, at ved den tid, da den skarpe regn faldt paa Island, merkede man i Trondhjem og paa nogle andre steder i Norge, ligesaa paa Froroerne, meget usæedvanlig indtrangende regn, hvorved bladene paa træerne blev halv gjennembrændte og gresset tillige sortagtigt. Paa Freroerne faldt tidt temmelig sand, aske og "svovldunst", som gjorde jorden overalt sort, naar vinden blreste af nordvest fra Island. Mange skibe, som reiste mellem Island og Kjobenhavn merkede og, at seilene og dekket var sort af sandstov.

Den ovenomtalte stovtaage medforte efter sommeren 1783 ikke stinkende luft, naar undtages et par dage sidst i april maned, da man mærkede stærk svovlet lugt endog paa Skílholts bispegaard. Medens Stephensen opholdt sig paa Siða i juli maaned 1784 blev luften altid ved nordlige vinde meget stinkende af svovl og særdeles ufordragelig især ved solens opgang, saa at han ofte ikke uden stor besværlighed kunde drage ande i teltet.

Den nedfaldne aske og grus gav i Vestre Skaptafellssyssel indsøerne en usædvanlig blat, undertiden noget gulagtig farve, ja søerne blev saa mraadne» og stinkende, at dode orreter fandtes opdrevne ved bredderne. Derimod fangedes i 1783, da Skaptí udtorredes, en mengde stor lax eller rettere orreter (silunger), der blev indestrengt i kulper.

Sveimn Pálsson fortæeller, som for berettet, at medens det saakaldte „Eldvatu foran den vestlige lavastrøm endnu var lunkent, sogte en ualmindelig mængde orret op i vandet, hvortil gruuden antages at være de mange myg og andre insekter, hvoraf de omliggende egne hjemsogtes efter udbrudet. Det er almindelig erfaring, at mange insekter udvikles omkring nylig flydte lavastromme paa. Island, idet vel varmen begunstiger deres udvikling. Stephensen beretter, at om sommeren 1783 vrimlede markerne af smaa paa Island ukjendte insekter, der havde en blaa, rod, gul eller brun farve, og som syntes mest at ligne jordlopper. De var til stor uleilighed for hostfolkene, som i faa minuter blev overdækkede af disse forhadte gjæster fra hoet.

De fugle, som for lagde ag til fjelds, blev fordrevne ved udbrudet og fornemmelig svanerne, der fielder fjer i angust maned, og som da pleiede at blive fangne i mængde. Man merkede det forste aar over hele. Island, at fugle som andre dyr vantrivedes; det varede kun nogle faa aar, at svanerne var fordrevne.

I. Skaptafellssyssel, hvor markerne blev overtrukne med sort dyud, blev græesvexten strax odelagt. Men ogsaa udenfor den egn, hvor sand og aske faldt i mængde, blev græsvæxten med et standset. Urterne fortorredes og blev sprode. Steingrimsson beretter, at det lidet ho, som man fik, var saa pestbefængt, at hvis det kastedes paa ilden, saa blev luen blaa af den svovl- og sandart, som var i det. Man/var allerede om hosten nødt til at nedslagte en trediedel, paa sine steder halvdelen af' buskapen. 
Pladsé for marehalin eller sandharre, hvillen vext var en vigtig artikel i husholdningen," blev odelagt paa flere steder i Skaptafellssyssel, idet de oversvommedes af lava. Ligesaa blev den i.landske mos (fjallagro-), som man pleiede at indsimle til vinterforratad, hegravet under aske oy sand paa de steder ovenfor Sida, hror den indsamledes, og det samme var tilfalde med de rodder (hvanmarot eller angelikarodder og andre rodder), som almindelig benyttedes til fode.

- Til at give et begreb om, hvor fordærveligt dette udbrud var for Island, kan folgende tal tjene: Ialt dode paa Island i aarene 1784-85 9238 mennesker af en befolkning paa 47287 eller en fémtedel af oens befolkning. I sogne, hvor der ellers pleiede at do 20 mennesker, dode nu 200. Hester og kvæg dode i tusenvis, som folgende tabel viser:

\begin{tabular}{|c|c|c|c|}
\hline 1783. & Deraf døde $1783-84$. & Levede 1784. & Af hvert 1000 dode. \\
\hline Kjør 21457. & 11461. & 9996. & 524. \\
\hline Sauer 232731. & 190488. & 42243. & 818. \\
\hline Heste 36408 . & 28013. & 8395. & 770. \\
\hline
\end{tabular}

Efter tabeller fra biskop Arni pórarinsson paa Hólar fandtes i hans stift:

$\begin{array}{lrc}\text { Syssel. } & \text { Ode Gaarde. } & \text { Mennesker dode af mangel. } \\ \text { Pingeyjar } & 129 . & 863 . \\ \text { Eyjafjardar } & 58 . & 518 . \\ \text { Skagafjordar } & 58 . & 462 . \\ \text { Hrinavatns } & 70 . & 302 . \\ & 315 . & 2145 .\end{array}$

Sveim Pálsson beretter, at i aarene 1784-86 var der paa Island 2584 fodte, mod 13030 dode, altsaa 10446 flere dode end fodte.

II Vestre Skaptafells syssel, hvor markerne blev overtrukne med det sorte dynd eller den ved skylregnen sammenblandede giftige aske, sand og svovlstov, hvor de nedfaldne gloende stene og aske havde bortsvedet alt græs af jorden, hvor en stinkende og kvælende rog, uveir, idelig lynen, torden og dundren i luften, svære underjordiske knald og heftige jordrystelser, hvor en forfærdelig ildflod af frembrusende, gloende lava; kort! hror fast alle de skrækkeligste omvaltninger i naturen havde ligesom forsamlet sig i et, der matte naturligvis kreaturerue lobe omhing par markerne som rasende; $\mathrm{og}$ da de ingensteds kunde finde tilflugt eller fode, og intet se, uden forskrekkelse fra alle kanter, hvad under da, at de endog have kastet sig i selve ilden. Sauerne og hestene adspredtes, saa neppe halvdelen af de forste kunde gjenfindes, og skjont de ved udbrudets begyndelse var $\mathrm{i}$ godt hold efter den milde vinter og det yndige foraar, saa styrtede de dog $\mathrm{i}$ hobetal en 8 a 14 dage efter af hidsig sygdom foraarsaget af den forgiftede fode. Man lagde i Skaptafells syssel mærke til, at sauerne, som cllers paa Island almindelig soger imod vinden, altid vendte sig fra denne, efterat ilden var udbrudt, formodentlig fordi de ikke kunde udstaa den stinkende svorllugt, som vinden forte med sig. Da kulden, som for omtalt, var meget igjennemtrængende, saa sogte de bestandig hen til lavastrommen, og de blev da undertiden overraskede og opbrændte af den fremveldende strøm, ja paa nogle steder har man trods al anvendt umag ikke kunnet holde dem tilbage. Om sauerne siger Steingrimsson, at de gik $\mathrm{i}$ ilden, $\mathrm{i}$ vandet $\mathrm{og}$ i havet, og alle vanskelige overfartssteder blev deres bane.

Fremideles bemærkede man, at sauerne om sommeren 1783 tvert imod deres natur og den almindelige erfaring har skyet hoie og torre steder, ja endog de græsrigeste heier; naar de blev 
drevne tilfjelds, har de efter $\mathrm{i}$ nogen tid at have lugtet til jorden og sogt $\mathrm{i}$ græsset, vendt tilbage til myrer og fugtige steder. Aarsagen hertil antages at være den, at asken og sanden her tildels sank ned i vandet paa de fugtige steder, $\mathrm{og}$ at græsset her efter indfaldet regnveir var mere forfrisket.

Ud paa vinteren mærkede man, at det hø, som var indsamlet, var udueligt, og kreaturerne kunde ikke trives, hvorfor man om vinteren var nodt til at slagte en del af dem.

Da sauerne om høsten $1783 \mathrm{kom}$ tilbage fra fjeldene, fandt man nogle af dem befængt med en ubekjendt sygdom. De kunde hverken staa eller gaa, tænderne var løse, saa at de ikke mer kunde tygge, kindbakkerne var besatte med knuder og ledene forknyttede. Der saaes efter Steingrimsson neppe et lem, som ikke var knudet, saa knoglerne stod ud af skindet. : Brystbenene og hoftebenene ligesom fodbenene kom af lave, saa at fødderne stod paa kryds. Henimod jul begyndte denne sygdom at ytre sig endog hos staldfodrede faar saavelsom hos hornkvæget, og dette maatte da nødvendigt nedslagtes, da ingen redning mer var tilovers. Af kjørene faldt hele eller halve halen, og kloverne faldt af eller kløvedes. Men de kalve, som fødtes i den tid af ganske udmagrede og marvløse mødre, fandtes med ganske marvfulde ben. Mange styrtede, for man havde formodet, da sygdommen oftere havde angrebet de indvortes end de udvortes dele. Saaledes fandt man undertiden, hjertet, lever, lungen og nyrerne i disse elendige skabninger overalt besatte med bylder $\mathrm{og}$ undertiden stærkt opsvulmede eller $\mathrm{og}$ fortærede $\mathrm{og}$ udhulede, samt det ene af nyrerne meget opblæst, det andet derimod meget sammenkrympet. Kjævebenene var gjennemædte, ligesom de kunde være overskaarne. Benene oplostes ligesom til brusk, og de haardeste knokler blev ved kogningen endog saa sprøde, at de med blotte hænder kunde plukkes ganske fra hverandre.

Det var fortrinsvis lam og unge faar, som blev angrebne af denne sygdom, uden at dog gamle og fuldvoxne sauer blev forskanede.

Alt kjødet af sauerne var ramt og fuldt af forgift, siger Steingrimsson, saa at spisningen af samme blev mange mænds bane.

Denne sygdom ytrede sig ogsaa iblandt hestene i Skaptafells syssel. Man saa dem styrte paa græsrige marker, og de vilde heller spise tømmer af huse og haarene af hverandre end det græs, som stod tilbage paa markerne fra aaret 1783. Saalænge kreaturerne kunde fodres med gammelt ho fra 1782, holdt de sig friske. Steingrimsson siger, at der, hvor han boede, levede 20 kjør om vaaren, men de fleste døde aaret efter. Faa heste overlevede vinteren. Søndagen den 9de november styrtede 20 heste under kirkefolket mellem Hørgsland og Breiðabólstaðr.*) Tagl og manke raadnede af hestene, rygskindet raadnede bort, og huden losnede af; hovedet trutnede over enhver beskrivelse, der kom magtløshed i kjæverne, saa de kunde ikke bide græs.

Da fædrift er eneste hovednæringsvei for befolkningen paa Islands sydkyst, og da kvæget blev sygt og elendigt, saa rasede snart sygdom og hungersnød ogsaa blandt befolkningen efter udbrudet. Sygdommen, ondartet skjørbug, visseligen fremkaldt ved knap, bedærvet og usund næring, ytrede sig for det meste paa samme maade hos menneskene som hos dyrene. Fødder, laar, hofter og arme tilligemed hals og hoved blev forskrækkelig hovne og opsvulmede, især over knæer, ankler og alle ledemod, hvilke sidste, ligesom ribbenene, blev forknyttede. Tænderne løsnedes og skjultes af det

*) Da det led ud paa vinteren, var ingen hest paa Sida saa stærk, at den kunde bære lig til kirken undtagen en, som Steingrimsson eiede, og som han havde kjøbt om høsten. Den feilede aldrig noget, hvor meget den aad af pesthøet, og folk forundrede sig meget over dens velbefindende. Det var en gammel, fed ridehest. 
hovne og forvoxne tandkjød, hvoraf tilsidst udfaldst store forraadnede stykker af sort, undertiden blaaggtig farve. Paa ganen $\mathrm{og}$ halsen ud- og indvendig kom store ildelugtende saar, ja tungen raadnede ud af munden, og brystsvaghed og blodgang plagede mange folk tildøde med de storste kvaler. Man kan næsten sige, at alt var sygt til døden, mennesker og dyr, siger Steingrimsson. Om vinteren og vaaren 1784 rasede denne sygdom næsten paa hver gaard $\mathrm{i}$ nærheden af vulkanen, men udenfor Vestre Skaptafells syssel ytrede den sig ikke i saa høi grad og med saa slemme tilfælde. Dyrtid og hungersnød, hvis lige Islands historie neppe kan opvise, fulgte paa udbrudet. Efterat de af sult og sygdom styrtede kreaturer var fortærede, havde man paa mange steder lidet eller intet til at opholde livet med. Somme tog hø og blandede det med mel og gjorde deraf grød, kager $\mathrm{og}$ brød. Alle fiskeben, som fandtes, baade hjemme $\mathrm{og}$ ved søen, blev tagne $\mathrm{g}$ fortærede. Nogle maatte hjælpe sig med raa skind, gamle huder og reb. Nogle kogte koskind, skar det i stykker, nedlagde det siden $\mathrm{i}$ sur valle og spiste det efter nogle dages forløb. Man bragte derved i erfaring, siger Steingrimsson, at skind af en fuldvoxen stud saaledes behandlet var fuldkommen saa drøit som 60 pund tørfisk.

Om vaaren, da græsset begyndte at gro, blev alt det, som spirede frem, tilligemed forskjellige rødder, benyttet dels til ernæring, dels som lægemiddel mod sygdommen. 


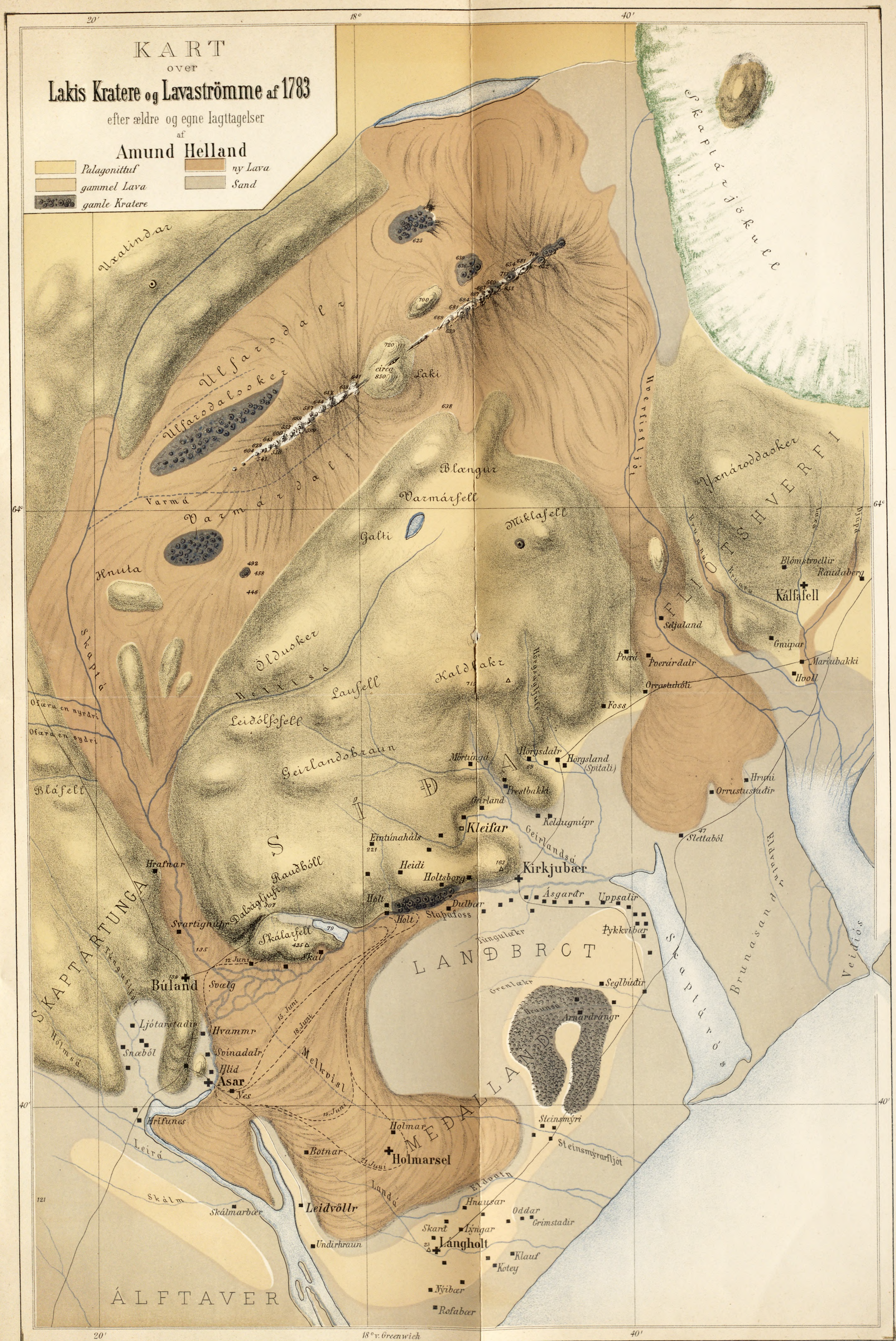


बassam ap a 